\title{
CROWDED DOCKETS AND THE COURTS OF APPEALS: THE THREAT TO THE FUNCTION OF REVIEW AND THE NATIONAL LAW
}

\author{
Paul D. Carrington*
}

The federal courts of appeals were designed to relieve the acute congestion in the Supreme Court, but the doctor has caught the disease. The caseload of these courts has doubled within the last eight years, and the rate of growth continues to climb. Numerous proposals for averting a crisis have been made, but many of them either are simply stopgaps or are so drastic that they threaten the twin functions of the courts: the institutionalization of decision making and the creation of a stable body of national law. Professor Carrington suggests a combination of measures designed to relieve the pressure while preserving as far as possible the national role of the courts of appeals.

$\mathrm{T}$ HE United States courts of appeals have just completed their third quarter-century of service. For most of us, this observation comes as a surprise. These courts became fixtures of our government so quickly after their creation by the Evarts Act in $189 \mathrm{I}^{1}$ that it is difficult to envision the judicial system of the United States without them. Despite far-reaching changes in the social and economic environment, the Judiciary Act of $1925^{2}$ has been the only subsequent major revision of the structure of the federal judiciary, and it made no fundamental changes, but simply extended the reforms of the Evarts Act by increasing our reliance on the courts of appeals in situations where the Evarts Act had been reluctant to trust the new creation. If we count the acts of $1789,{ }^{3}$ I $80 \mathrm{r},{ }^{4} \mathrm{I} 837,{ }^{5}$ and $1875^{6}$ as the other major re-

* Professor of Law, Michigan Law School. B.A., Texas, r952; LL.B., Harvard, 1955 .

Many of the ideas contained here originated with the Advisors to the American Bar Foundation Study of the United States Courts of Appeals, of which the author was Project Director. The Advisors, none of whom bears responsibility for the conclusions advanced here, were Dean Lindsey Cowen, Judge Charles S. Desmond, Nathan B. Goodrow, Esq., Leon Jaworski, Esq., Professor David W. Louisell, Justice Thurgood Marshall, Judge Carl McGowan, Professor Paul J. Mishkin, and Bernard G. Segal, Esq. A project report summarizing the views of the Advisors has been published by the Foundation as AccommodatnNG THE WorkLOAD of the United States Courts of Appears (rg68). The author also wishes to acknowledge the many lawyers, judges, professors, and students, too numerous to permit individual mention, who have responded to his pleas for help.

${ }^{1}$ Circuit Court of Appeals Act of $189 \mathrm{~g}$, ch. 517, 26 Stat. 826.

2 Ch. 229, 43 Stat. 936.

${ }^{3}$ Judiciary Act of 1789 , ch. 20, I Stat. 73.

${ }^{4}$ Act of Feb. 13, I80I, ch. 4, 2 Stat. 89.

5 Act of Mar. 3, 1837 , ch. 34, 5 Stat. 176.

${ }^{6}$ Judiciary Act of 1875 , ch. 137,18 Stat. 470 . 
modelings, we have now set a new record for consecutive years of restraint from tinkering with the system. There can be no doubt that the system has worked well; the courts of appeals have made effective use of the services of some of our ablest judges. Nevertheless, we must recognize that "great judiciary acts, unlike great poems, are not written for all times." 7 The existing framework is being strained by the rapidly increasing number of appeals in the federal system.

This article will examine the dimensions of the problem of congestion in the federal courts of appeals and will consider various means of dealing with it. Parts I and II suggest that the federal appellate caseload is likely to continue to increase for the foreseeable future and that the resulting congestion poses a serious threat to the institutional role of the courts of appeals. Parts III and IV discuss some frequently suggested means for dealing with the problem by increasing the efficiency of the courts or by imposing restrictions on the right of appeal. Since these methods appear to be either inadequate, incomplete, or undesirable, the only solution to the problem seems to be an increase in the number of appellate judgeships. Part $V$ considers means of accommodating such an increase without impairment of the separate courts of appeals. It is concluded, however, that such devices for accommodation are defective, for they fail to meet the risks of harm to the stability of the national law which results from divergences among the circuits. Part VI therefore considers methods of restructuring the federal appellate system to obtain greater national harmony.

\section{Congestion in the Courts of Appeals}

In their early years of operation, the courts of appeals sometimes entertained as many as eight hundred appeals. ${ }^{8}$ By I924 that number had more than doubled. ${ }^{9}$ By I960 it had doubled again. ${ }^{10}$ In r 966 the number had almost doubled yet again. ${ }^{11}$ The puzzling spurt in the number of appeals in recent years has occurred while the caseloads of the district courts have grown much more slowly. ${ }^{12}$ The causes of such growth, far greater than the rate of increase of population, are not easily identifiable.

${ }^{7}$ F. Frankfurter \& J. Landis, The Business of the Supreme Court io7 (1927).

${ }^{8} I d$. at 298.

${ }^{9} I d$.

${ }^{10}$ Ig6o Annual Report of the Director of the Administrative Office or the UnIted States Courts 210 [hereinafter cited as ANNUAL Report preceded by the year].

11 I 966 ANNUAL REPORT I49.

${ }^{12}$ See I967 ANNUAL RePORT I02, II2, I2I. 
To some extent, the larger caseload reflects an increased amount of criminal litigation. The number of appeals from convictions increased from 623 in 1960 to 1665 in 1967 , and the number of appeals from denials of postconviction relief increased from 290 to $1335 .{ }^{13}$ These phenomena are largely explained by the requirement that counsel and free transcripts be provided for indigent defendants and by other changes in the field of criminal law and procedure. ${ }^{14}$

More puzzling is the increase in the number of civil appeals; with prisoner petitions excluded, the number has increased in the present decade from 2322 to $4473 .{ }^{15}$ The rate of appeal has increased markedly in every circuit but the First, ${ }^{10}$ and no pattern can be found relating the increase to the subject matter of the case or the decision maker being reviewed.

Several partial explanations for the higher rate of appellate litigation are apparent. One is the change in the substantive character of federal trial court litigation. Thus, there has been a marked increase in civil rights litigation as a portion of the mix; the number of such actions terminated in district courts increased four-fold from the biennium $1959-1960$ to the biennium r966-r967. Losers in civil rights cases tend to appeal more often; thus there is a disproportionate increase in the appellate burden. ${ }^{17}$ Likewise, the litigation arising from the Labor-Management Reporting and Disclosure Act of $1959{ }^{18}$ seems to have contributed to the rise in the same way. ${ }^{10}$

A second factor has been the judgeship acts of r96r and $1966,{ }^{20}$ which created respectively sixty-three and thirty additional district judgeships; the energies of the new judges seem to have been absorbed by the growing demands of criminal litigation and

13 Compare ig6o ANNuAL RePORT 222-23 with I967 ANNuAL Report 192-94.

${ }^{14}$ See, e.g., 18 U.S.C. \& 3006A (I964); Miranda v. Arizona, 384 U.S. 436 (rg66); Gideon v. Wainwright, 372 U.S. 335 (I963); Griffin v. Illinois, 35 I U.S. I2 (x956).

15 Ig60 ANNUAL REPORT 210; I967 ANNUAL RePort 180.

${ }^{16}$ Compare 1960 ANNUAL RePORT 210-13 with I967 ANNUAL RePORT 180-83.

${ }^{17}$ In 1967,647 private civil rights cases were terminated by action of district courts, and $\times 74$ appeals were filed in such cases; thus, more than one in four terminations resulted in appeal; for all other civil cases the totals were 36,908 terminations and 4299 appeals, or a rate of about one in nine. 1967 ANNunL REPORT I92-93, 216-r8.

${ }^{18} 29$ U.S.C. $\$ \S 40 I-53$ I (1964).

${ }^{10}$ In I960 there were 275 private labor relations cases filed in the district courts. 1960 ANNUAL REPORT 250. In 1967 , the number of such filings was 937. 1967 ANNUAL REPORT 2I7. The ratio of appeals to terminations in such cases was about one to four in 1967 . Id. at $193,21 \%$.

${ }^{20}$ Omnibus Judgeship Act of I961, Pub. L. No. 87-36, $\$ 2$ (d), 75 Stat. 80 (codified at 28 U.S.C. $\$ 133$ (1964)); Act. of Mar. I8, 1966, Pub. L. No. 89-372, § 4 , 80 Stat. 77 (codified at 28 U.S.C. \$ 133 (Supp. II, 1967)). 
The Appellate Caseload by Subject Matter:

Two BIENNIA COMPARED 21

\begin{tabular}{lcc}
\hline \hline Type of Suit & & \\
\hline Administrative Appeals & 1343 & 1966-1967 \\
Labor Relations (NLRB) & 602 & 2639 \\
Utilities \& Transportation (CAB, FCC \& FPC) & 213 & 383 \\
Other & 528 & 1049 \\
District Court Civil Appeals - United States a Party & 1590 & 2710 \\
Contracts and Negotiable Instruments & 122 & 226 \\
Eminent Domain & 63 & 164 \\
Prisoner Petitions & 327 & 413 \\
Taxation & 358 & 803 \\
Tort Claims & 95 & 233 \\
Other & 625 & 871 \\
District Court Criminal Appeals & 1041 & 3123 \\
Private Federal Question Litigation & 1041 & 3509 \\
Antitrust & 81 & 144 \\
Civil Rights & 100 & 360 \\
Miller Act (Government Subcontractors) & 36 & 98 \\
Labor Relations & 136 & 284 \\
Patents and Trademarks & 196 & 271 \\
Prisoner Petitions & 200 & 1604 \\
Other & 292 & 748 \\
Diversity Litigation & 1496 & 2004 \\
Insurance & 230 & 442 \\
Other Contracts & 444 & 613 \\
Personal Injury & 555 & 754 \\
Other & 267 & 195 \\
Other Litigation & 944 & 1101 \\
Total & 7455 & 15,086 \\
\hline \hline
\end{tabular}

prisoner petitions. There has also been a rise in the percentage of civil cases not disposed of until after trial. ${ }^{22}$ The connection here is uncertain, but it might be that as the new district judges have begun to cut into backlogs, the pressure to settle has diminished, and more litigants are disposed to await the outcome of trial. ${ }^{23}$ For similar reasons, with trials completed more quickly, litigants may be more willing to put up with the delays of appealing rather than settling. It is also possible that the relatively inexperienced trial judges appointed pursuant to the I96I and $x 966$ Acts have been somewhat more prone to commit reversible error.

\footnotetext{
21 I959 ANNUAL REPoRT I70, x78-79; x960 ANNUAL Report 210, 2I7, 222-23; I966 ANNUAL REPORT I6I-63; I967 ANNUAL RePORT I86, I92-95.

22 The figures are $9.7 \%$ in 1960 and $10.9 \%$ in 1967 . See 1960 ANNUAL RePORT 252; I967 ANNUAL REPORT 216.

23 This reaction to backlog cutting is analyzed in H. ZeISEL, H. Kalven \& B. BuchHolz, Delay IN THE COURT II, III-I9 (I959).
} 
These possibilities seem to be neither proved nor disproved by the fact that the aggregate reversal rate has remained constant while the rate of appeal has risen. ${ }^{24}$

The increased propensity of federal litigants to appeal might be explained in part by changes in the popular and professional attitude toward the role of the appellate process. These changes are reflected in the increased activism of the Supreme Court. They may be related to the emergence of legal realism, which has taught us that legal doctrine is less compelling than our forebears proclaimed and that the personal responsibility of judges is greater than they admitted. Today, fewer individual problems seem too small to be deserving of presentation to higher courts, and fewer problems seem so large as to confound the power of the judicial system. ${ }^{25}$

This change in attitude affects not only litigants and their lawyers but also appellate judges, who in meeting their felt obligations are forced to involve themselves more deeply in the details of the decision making at the trial court level. ${ }^{26}$ Moreover, judges with a heightened sense of personal responsibility and a diminished sense of the importance of stable doctrine are more prone to innovate to meet the needs of the moment. Hence, courts are a more inviting arena in which to wage a social struggle. However, this explanation leaves open the question why similar trends are not apparent in the appellate courts of California and New Jersey, for those courts have been at least as innovative in recent years as the federal courts. One is tempted to speculate that the rising rate of appeal reflects in part a national attitude which is increasingly distrustful of high officials; this attitude might be most evident in the courts of appeals, since district judges and other federal officials may be challenged there directly, and state officials may be brought in by actions under the Civil Rights Acts. ${ }^{27}$

Certain other factors that may come readily to mind in an attempt to explain the rising number of appeals may be dismissed as having only negligible impact. For example, in r958 legislation was enacted authorizing interlocutory appeals in certain cases, ${ }^{28}$ but in 1967 only eighty petitions for interlocutory appeal

${ }^{24}$ The reversal rate is down slightly for bankruptcy cases and appeals from administrative agencies. Compare I960 ANNUAL REPORT 210 with 1967 ANNUAL REPORT I80.

${ }^{25}$ Cf. Goldberg, Equality and Government Action, 39 N.Y.U.L. REv. 205 (1964).

${ }^{26}$ Cf. Wright, The Doubtful Omniscience of Appellate Courts, 4I MunN. L. REv. 75 I (1957).

${ }^{27} 42$ U.S.C. $\S \S 1981-83$, I985 (1964).

${ }^{28}$ Act of Sept. 2, I958, Pub. L. No. 85-919, 72 Stat. I770 (codified at 28 U.S.C. $\S$ I292(b) (Ig64)). 
were considered. ${ }^{29}$ An explanation with superficial attractiveness is that rising affluence has brought the costs of appeal within reach of a larger number of litigants, but this explanation must be rejected for several reasons. The courts of appeals' caseload curve bears almost no resemblance to any economic index. It is unlikely that the Government or the many corporations who form the bulk of federal civil litigants operate on so close a margin as to be affected dramatically by economic factors. It is also unlikely that the relative cost of appeal has decreased noticeably. Finally, the stimulated propensity to litigate seems to be focused on the federal courts. ${ }^{30}$

It seems necessary to conclude that no evidence can be found to give adequate support to any theory fully accounting for the rising rate of appeal in federal courts. At the present time the causes of litigation, like the causes of many other forms of behavior, are too rich a mix to be susceptible of scientific methods of proof. Thus, we know that the Japanese ${ }^{31}$ and the British ${ }^{32}$ tend to be less litigious than Americans, and that New Englanders tend to be less litigious than Texans or Californians, but we can do little more than speculate as to the causes of these phenomena. This fact accentuates the difficulty in which the courts of appeals are presently to be seen. Not only must some adaptation be made to accommodate increased numbers of litigants, but adjustments must be made without a clear understanding of the causes of the new congestion.

If the causes of the present congestion are not fully known, it is soothsaying to try to predict their future effect. Statistical methods are of little additional value: ${ }^{33}$ just as the flat curve in docket growth during the late fifties was not a reliable indicator of the pattern of the sixties, so the nearly perpendicular curve of recent years may not describe the future at all. Nevertheless, it seems helpful to seek agreement that although the demand on federal appellate courts is likely to fluctuate, it will continue to grow.

There are no visible factors that seem likely to diminish the rate of appeal. The factors influencing the rate in criminal cases

\footnotetext{
20 ig67 AnNuat Report igi.

so This assertion is difficult to support. Examination of data for those states which keep detailed statistics, such as California, New Jersey, New York, and Wisconsin, fails to reveal any pattern of a rising rate of appeal.

${ }^{31}$ A statistical study of Japanese litigation is contained in Kawashima, Dispute Resolution in Contemporary Japan, in LaW IN JAPAN 4 I (A. von Mehren ed. I962).

${ }^{32}$ There were but 700 civil appeals in England and Wales in I96r. D. KARLEN, Appellate Courts in the United States and England i26 (ig63).

${ }^{33}$ But cf. Shafroth, Survey of the United States Courts of Appeals, 42 F.R.D. 247, 26r (I967).
} 
and prisoner petitions seem likely to maintain a continuing upward pressure. The Criminal Justice Act ${ }^{34}$ is still far from achieving full impact in providing vigorous defense for persons accused of crime. ${ }^{35}$ More important, the scope of review in criminal cases seems almost certain to be expanded in the near future to include review of sentences. ${ }^{36}$ As far as the rate of appeal in civil cases is concerned, the contributing factor of increased awareness on the part of the bar of the potential uses of appellate review seems unlikely to diminish.

The pressure on the federal trial courts is even more likely to continue its growth, perhaps at a more rapid pace. While we have seen that the appellate docket can grow quite disproportionately to the trial docket, more primary litigation will surely produce more appellate litigation unless independent influences are at play. It is possible that some pressure on the docket has been dammed up by the failure of the Justice Department to grow commensurately with the demands suddenly placed upon it ${ }^{37}$ creating pressure on the Government to plea bargain and to settle civil disputes.

It seems quite likely that the United States will become involved in more civil disputes in the future. This prognosis rests not merely on a prediction that the Government will be involved in more and larger programs involving a larger number of potential adversaries, but also on a prediction about the attitude of those potential litigants toward litigation. A modern trend has favored subsidy over regulation for new programs. To an

\footnotetext{
${ }^{34}$ I8 U.S.C. $\$ 3006 \mathrm{~A}$ (1964).

${ }^{35}$ There may be some offsetting relief in a decrease in the number of prisoner petitions as the questions raised by those petitions come to be more fully litigated on direct review. But see Wright, The Federal Courts - A Centıiry After Appomaltox, 52 A.B.A.J. 742,747 ( 1966 ). But this decrease will be slow in coming among state prisoners.

${ }^{36}$ Legislation to this effect was recommended by the Judicial Conference. 1964 Reports of the Proceedings of the Judicial Conference of the United States 86. See also Advisory Comm. on Sentencing and Review, ABA Project on Minimum Standards for Criminal Justice, Standards Relating to AppelLATE ReView of Sentences (tent. draft I967).

Other developments which may have some impact on the criminal caseload include increasing judicial involvement in the oversight of prison administration, see, e.g., Wright v. McMann, 387 F.2d 519 (2d Cir. 1967); Johnson v. Avery, 382 F.2d 353 (6th Cir. 1967), cert. granted, 390 U.S. 943 (1968), and relaxation of standards of mootness in criminal cases, see Sibron v. New York, 392 U.S. 40, 50-58 (1968); The Supreme Court, 1967 Term, 82 HARv. L. Rev. 63, 296-301 (1968).

37 The total of the professional staffs of the United States Attorneys has increased from 732 in 1960 to 793 in 1966, and except for the Civil Rights Division, the number of attorneys assigned to the Justice Department has increased only slightly since I96r. Letter from Assistant Attorney General Barefoot Sanders to Paul D. Carrington, Jan. $7,1967$.
} 
increasing degree, such programs are regarded less as acts of grace by a benevolent government, and more as a source of proprietary rights that are suitable subjects of litigation, ${ }^{38}$ and it seems not unlikely that challenges will receive a hospitable hearing in the federal courts. The program of the Office of Economic Opportunity to provide legal services to the poor is quite likely to contribute to such a development. ${ }^{39}$ Moreover, there is no reasonable prospect that any of this public litigation might be transferred to state courts.

The prospects for future diversity of citizenship litigation in the courts of appeals may be viewed somewhat more optimistically, despite the trend of steady growth in diversity appeals. There is some possibility that the diversity jurisdiction will be restricted. The American Law Institute has suggested changes which would reduce the diversity caseload in the district courts by as much as one-half. ${ }^{40}$ Presumably this saving would be reflected in the appellate caseload as well, but this is not clear.

The prospect for growth seems more certain with respect to private federal question litigation, where many of the reasons indicating a growth in public civil litigation are also operative. The increasing size and cohesiveness of the national economy and the growing scope of federal control make it quite likely that the federal courts will play an increasingly important role in the resolution of disputes, and the trend may very well be accelerated by the enlargement of the federal question jurisdiction of the district courts suggested by the ALI. ${ }^{41}$

For all of these reasons, it seems unlikely that the problem of congestion in the courts of appeals will solve itself in the foreseeable future. Before turning to a discussion of possible remedies, however, it is appropriate to examine the social costs of congestion in order to be able to appraise both the seriousness of the problem and the amount we should be willing to pay to solve it.

${ }^{38}$ See generally Cahn \& Cahn, The New Sovereign Immunity, 8I HaRv. L. REv. 929 (I968); Lynn, Legal and Economic Implications of the Emergence of Quasi-Public Wealth, 65 YALE L.J. 786 (1956); Reich, Individual Rights and Social Welfare: The Emerging Legal Issues, 74 YALE L.J. I245 (I965).

39 See generally P. WAID, LAW AND PoverTy: I965 (Report to the Nat'l Conf. on Law \& Poverty 1965); Note, The Indigent's Right to Counsel in Civil Cases, 76 Yale L.J. 545 ( 1967 ).

40 Ali Study of the Division of Jurisdiction Between State and Federal CourTs $\S \S 1301-07$ (proposed final draft 1965). But see Frank, For Maintaining Diversity Jurisdiction, 73 YaLE L.J. 7 (I963); Wright, The Federal Courts and the Nature and Quality of State Law, I3 WAYNe ST. L. REv. 3I7 (I967). The ABA failed to approve the proposals. 36 U.S.L.W. 2I2I (I967).

${ }^{41}$ ALI Study of the Division of Jurisdiction Between State and Federat CoURTS $\$ § 13$ II-I5 (tent. draft no. 6, I968). 


\section{Congestion and the Mission of the Courts of Appeals}

\section{A. The Purpose of Review: Institutionalization of Decisions}

Any modern government must have some standards that can be communicated to its multiple decision makers if it is to maintain direction and the moral support of its citizens. Furthermore, its mandates must be sufficiently clear and reliable in their application that citizens can reasonably be expected to make their behavior conform. The necessity of entrusting the use of our principles to human decision makers introduces an unreliable element which makes the stated goal impossible of perfect achievement. The basic purpose of review is to minimize the resulting loss.

In contemporary discourse, the need for review has been most frequently expressed in the context of administrative litigation. Members of the most important federal agencies are appointed under circumstances intended to supply an independent measure of integrity, but there would be few today who would challenge the importance of judicial review to the health of their operations. Less often noticed today is the extensive sovereignty of the United States district judge, but a look at the history of the courts of appeals reveals that danger may come from this source too.

At the time of the Evarts Act, no appeals were allowed in criminal cases, ${ }^{42}$ and none were available in civil cases where the amount in controversy did not exceed five thousand dollars. ${ }^{43}$ Furthermore, the backlog in the Supreme Court was sufficiently great $^{44}$ that review was largely ineffectual even in those cases where it was available. Complaints about the lower federal judges were frequent and vigorous. In 1890 , speaking on behalf of the bill that ultimately became the Evarts Act, Representative Culberson admitted to "a supreme desire to witness during . . . [his] time in Congress the overthrow and destruction of the kingly power of district and circuit judges." 4i The trial judge is in a unique position of authority over the day-to-day actions of individuals. It is his everyday duty to make decisions which may deprive a man of his fortune or his livelihood, or require him to perform or refrain from action, or cause him to be imprisoned or put to death. Megalomania is an occupational hazard of the judicial office.

But the function of review is not only to prevent gross abuses

\footnotetext{
42 United States v. More, 7 U.S. (3 Cranch) 159 (1805).

${ }^{43}$ Act of Feb. 16, 8875 , ch. $77, \S 3$, 18 Stat. 471 .

${ }^{44}$ See generally F. FRANKFURTER \& J. LANDIS, supra note 7, at 56-58.

45 II CoNG. ReC. 3403 (I89o).
} 
of authority. The judge responsible for making primary decisions must necessarily make a heavy investment of time and interest in particular disputes and individuals that come before him; his limited perspective and his limited opportunity for reflection make it impossible for him to coordinate successfully with his colleagues. Vanity and pride of opinion are additional obstacles; even very sensitive, intelligent, and self-disciplined judges must be troubled at times by their own involvements of ego. By providing supervision, we keep the various decision makers operating within an institutional framework. Remoteness of the reviewer from the firing line of trial can assure greater objectivity for the institutional process. By employing a larger group of decision makers than can be efficiently employed at the primary level, we bring a broader base of values into operation so that the personal dimension of decisions is diminished. The process of review permits a larger number of decisions to be harmonized under the aegis of a single authority. Moreover, review spreads the responsibility for decisions more broadly. Thus the mistakes may be more bearable to the individuals affected, and the judicial office is made a tolerable employment for men of ordinary sensitivity. Review is, therefore, essential to the goal of law.

\section{B. Creating and Enforcing the National Law}

In addition to serving as a check on the power of district judges and administrative agencies, the courts of appeals have a related function in helping to create a stable body of national law. The need for judicial creativity in the federal courts is too well known to require elaborate discussion. ${ }^{40}$ It results from the legislative inability to foresee and resolve every situation which will arise, from planned ambiguity in statutes or deliberate quitclaims of groups of problems to the courts, and from muddled legislation, as a result of either carelessness or the practicalities of the legislative process.

Creativity, however, must not be carried so far that it destroys the stability of doctrine. Predictability is essential not only to lawyers who must advise their clients about the national law; it is of central importance if review is to achieve its intended purpose. Review without cogent legal principles by which primary decisions can be measured is like Hamlet without the prince.

${ }^{48}$ See generally H.M. Hart \& A. Sacks, The Legar Process: Basic ProbIEMS IN THE MAKING AND AppLICATION OF LAW Ir44-I4I7 (tent. ed. I958); Friendly, In Praise of Erie - And of the New Federal Common Law, 39 N.Y.U.L. REv. 383 ( 1964 ). 
At some point, flexibility of doctrine poses a threat to the integrity and independence of the federal judiciary. Our judiciary is perhaps unique in the importance of its role in the national life. Influenced by Blackstone's assertions that judges do not make law but declare it, our forebears were frequently willing to regard the judiciary as part of a system that was beyond the proper arena of social struggle. This made the tradition of judicial independence possible. ${ }^{47}$ Once established, this tradition is probably able to survive legal realism, which reveals the judicial power as a useful weapon with which to wage social combat, although the revelation itself tends to impair the judicial process as a means for resolving such struggles. But increasing doctrinal instability enlarges the threat. ${ }^{48}$ It brings home the truth of the teachings of legal realism which personalize the responsibility of the individual judge and thereby weaken the popular base on which judicial independence must rest. An unstable, personalized legal system invites political assault and subversion and is less able to withstand them than is a system with greater doctrinal stability and greater subordination of the personality of the individual judge. ${ }^{49}$ The status and responsibility of our judiciary is thus related to the accustomed capacity of our courts to supply principled decisions.

Reviewing courts are in a far better position than trial courts to accommodate the need for stability with the need for flexibility and creativity. With more decision makers participating in the decision, and with greater opportunity for discussion and reflection, they are more capable of creativity where it is needed. On the other hand, since their decrees are binding over a wider territory than are those of trial courts and because they may be of greater persuasive value even outside the courts' own jurisdictions, the appellate courts are better able to maintain the necessary continuity of doctrine over time and space.

Initially, the task of overseeing the development of the national law was left almost entirely to the Supreme Court within the federal judicial system. The federal trial courts had no general federal question jurisdiction, ${ }^{50}$ so that most federal litigation

${ }^{47}$ See Cooperrider, The Rule of Law and the Judicial Process, 59 Micrr. L. Rev. 50r (I96I); Mishkin, Foreword: The High Court, the Great Writ, and the Due Process of Time and Law, 79 HARv. L. Rev. 56, 62 (1965).

${ }^{48}$ See Hart, Foreword: The Time Chart of the Justices, 73 HaRv. L. Rev. 84 (1959); Kurland, Foreword: "Equal in Origin and Equal in Title to the Legislative and Executive Branches of the Government," 78 HARv. L. REv. 143 (1964); Wechsler, Toward Neutral Principles of Constitutional Law, 73 HaRv. L. REv. I (I959).

${ }^{49}$ See generally A. Bicked, The Least Dangerous Branch (I962).

${ }^{50}$ H.M. Hart \& H. Wechsler, The Federal Courts and ture Federal System 727-33 (1953). 
was carried on in the state courts, subject to review by the Supreme Court. The grant of federal question jurisdiction to the district courts in $18755^{51}$ the creation of the courts of appeals in I $89 x^{52}$ and the enormous flood of federal litigation which resulted from the tide of federal regulatory legislation around the turn of the century resulted in the transfer of a large part of this burden to the courts of appeals.

The Supreme Court is no longer capable of providing the supervision of federal judicial law making that it once provided. An unofficial count reveals that of the II 9 full opinions handed down during the I966 Term, eighty dealt with cases from the courts of appeals. ${ }^{53}$ These cases represented about two percent of the decisions after hearing or submission in the courts of appeals in the preceding fiscal year. ${ }^{54}$ The number and type of cases decided in the Supreme Court by full opinion have remained fairly constant for quite some time. ${ }^{55}$ In light of the swelling dockets of the courts of appeals, it is apparent that ever larger segments of the national law must be entrusted to their care and maintenance.

This trend is also evident in the controlling legislation, as the provisions in the earlier acts for bypassing the courts of appeals in certain important classes of cases have gradually been repealed in order to lighten the pressure on the Supreme Court. The few remaining examples of such direct appeals - most notably the provision for review of orders of the Interstate Commerce Commission, ${ }^{56}$ the provision for direct appeal in government antitrust cases, ${ }^{57}$ and the provision for government appeals of some rulings in criminal cases ${ }^{58}$ - seem likely to be removed in the near future.59 While the effect of these changes on the caseload of the courts of appeals would be slight, ${ }^{60}$ they illustrate

\footnotetext{
51 Judiciary Act of 1875 , ch. 137 , I8 Stat. 470 .

52 Circuit Court of Appeals Act of I89I, ch. 5I7, 26 Stat. 826.

${ }^{53}$ The Supreme Court, rg66 Term, 8I HaRv. L. Rev. 69, I28-29 (1967).

${ }^{54}$ There were 4087 such decisions. Ig66 ANNUAL REPORT I49.

${ }^{55}$ See The Supreme Court, 1967 Term, 82 HaRv. L. Rev. 63, 3 10 (I968); The Supreme Court, Ig62 Term, 77 HARv. L. REv. 62, 83 (Ig63); The Supreme Court, 1957 Term, 72 Harv. L. Rev. 77, 99 (1958); The Supreme Court, 1952 Term, 67 HARV. L. REV. 9I, I74 (I953).

${ }^{56} 28$ U.S.C. $\$ \S 1253,2325$ (Ig64).

${ }^{57}$ I5 U.S.C. $\$ 29$ (1964).

58 I8 U.S.C. $\$ 373$ I (1964).

${ }^{50}$ See ICC v. Atlantic Coast Line R.R., 383 U.S. 576, 586 n.4 (1966); United States v. Singer Mfg. Co., 374 U.S. I74, I75 n.I, 202 (Ig63); C. WrIGHT, FEDERAI CouRTs $\S$ I05, at $4 \mathrm{I}_{3}-\mathrm{I}_{4}$ (I963) ; Friedenthal, Government Appeals in Federal Criminal Cases, I2 Stan. L. Rev. $7 \mathrm{r}$ (1959); Kurland, The Mersky Case and the Criminal Appeals Act: A Suggestion for Amendment of the Statute, 28 U. CHr. L. REv. 4 I9 (I96I).

${ }^{60}$ During the 1966 Term of the Supreme Court, there were 2 appeals under the
} 
our increasing reliance on those courts to create and enforce the national law.

\section{The Threats of Congestion}

A reviewing court confronted with an increasing number of appeals may either try to keep abreast or create a backlog. It might be thought that accumulation of a backlog would operate to curtail the flow of appeals, but it is unclear whether this is the case. ${ }^{61}$ In any event, delay itself is easily demonstrated to be an unqualified evil. ${ }^{2}$ It increases the pressure for settlement and improves the bargaining position of undeserving litigants who are sheltered by it. Delay may result in the deterioration of evidence and thus impair the ultimate quality of decisions in cases in which new trials are required. It creates a new issue relating to the order in which cases are to be decided: a court that is far behind must expedite some decisions at the expense of further delay to others. For all these reasons, appellate courts under pressure of the recent congestion have generally felt impelled to try to remain abreast of the caseload. ${ }^{63}$

The pressure created by trying to stay abreast of a congested docket, however, threatens the successful performance of the law-making function of the federal courts of appeals. The lawmaking role requires a delicate balance between the importance of flexibility in the national law and the importance of stability of doctrine. Busy judges will find it difficult to evaluate these needs in the cases that come before them, and they may be more tempted to take the shortcuts which can be made by ignoring one of the interests.

Congestion also threatens the effectiveness of review. Pressure of time may create a tendency to give greater deference to primary decision makers. In addition, there is a paradoxical prospect that increased appellate activity may impair the very

Criminal Appeals Act, $I_{5}$ appeals in ICC matters, and 7 direct appeals in antitrust cases.

${ }^{61}$ See F. Hamley, Selecting Cases for Appellate Review 4 (paper presented at the Appellate Judges Seminar, N.Y.U. Law School, July 18-Aug. 2, 1956, printed by the Institute of Judicial Administration).

${ }^{62}$ H. Zeised, H. Kalven \& B. Bucheolz, Delay in the Court xxii (1959). These authors find a single grace in delay by attributing to it the literary career of Goethe, who was discouraged from the practice of law by swollen dockets. Id. at xxiii-iv n.6. Regrettably, even this may be too charitable; a recent and authoritative biography does not find the state of the dockets worth discussing in analyzing Goethe's decision to leave law for poetry. R. FrIEdentHAx, GoetHe: His LifE AND TIMES 98, Iro- 17 (1965).

${ }^{63}$ Thus, although only 3713 cases were terminated in 1960 (out of 3899 commenced), see 1960 ANNUAL REPORT 210, in 1966 (when 7183 cases were commenced) the number terminated had risen to $657 \mathrm{I}$, see Ig66 ANNUAL RePORT 149. 
quality of the process that justifies its use. There is a danger that courts of appeals' decisions may themselves become more responsive to the personal values of individual circuit judges, and less responsive to the general and idealized values of the system as a thing apart from the individuals momentarily operating it.

Most of the features of the appellate process serve the purpose of urging the appellate judge out of the mold created by his own tastes and values. We rely on the adversary tradition to supply the court with the basic equipment for making impersonal, "rational" decisions. Appellate judges are expected to deliberate and then to arrive at a collegial decision based on the matured thought of each judge participating. Finally, the decision is expected to be explained in terms that will withstand public inspection. These techniques for controlling the personal factor require a considerable investment of time and intellectual energy; as congestion makes these commodities scarce, we must expect that judgments will become more impulsive, less reflective and less impersonal. Even the most industrious, detached, and selfless judge is bound to respond to the pressures of congestion, indeed, perhaps the more so for his sensitivity. If meritorious cases are being delayed, or receiving too little attention, the conscientious judge must respond to his impulses to cut short his deliberation over matters that seem less promising. As he does so, he is unmistakably transforming the character of his decision and the process by which it is made.

Reasonable minds may differ on the extent to which the internal controls within the reviewing process are needed in order to ensure adequate institutional review. All of the evaluations contained in this article rest on the premise that the existing controls are not superabundant, that only grudgingly should we weaken any of the institutional arrangements which are intended to prevent the personal values of individual judges from playing a larger role in influencing decisions. This premise rests on an intuition that implicit constraints are unstable and must be carefully nurtured upon pain of sudden, disintegrative effects, and that it would be far easier to witness a fairly rapid decline in the institutional integrity of the national legal process than it would be to rebuild that process to its present elevated status.

If it is accepted that the state of the dockets of the courts of appeals is or soon will be intolerable, some reform is necessary. But the problem is one which has limited dimensions: either the process must be made more efficient so that more decisions can be made by each judge; or the number of decisions must be held constant; or there must be more judges. It can be quickly recognized that any approach presents difficulties, and only in limited 
degree is it possible to avoid costs by a blending of alternative solutions. The remainder of this article will be devoted to a discussion of the costs and benefits of these alternatives.

\section{Administration: The Limits of Efficiency}

\section{A. Quasi-Judicial and Administrative Duties}

The courts of appeals have many tasks to perform which are peripheral to their mission and which might properly be delegated to persons other than judges without offense to the rights of litigants. Some of these may be classified as quasi-judicial because they require the making of decisions about cases, such as the selection and compensation of counsel representing indigents or the primary screening of prisoner petitions. Other delegable chores are purely administrative in character. These include duties pertaining to the internal operations of the court and its external relations with the bar and the public - for example, the supervision of the clerk's office and liaison with district courts and their administrators and with the Administrative Office in Washington. These are important duties, but it is not clear that they require the expenditure of the energy of circuit judges when that resource is in short supply.

The controlling legislation makes the judicial council of each circuit, presided over by the chief judge, responsible for the administration of the court, but no delegation is specified. ${ }^{04}$ The circuits vary in the extent to which the duties are performed by the chief judge or other circuit judges, by the clerk of the court, or by staff law clerks, but it seems clear that in each circuit a considerable load is borne by judges that could be borne by others. ${ }^{6.5}$ Some is direct; some is indirect and supervisory.

It is not an answer to rely upon the chief judge to see that all of these chores are performed. First, it may be observed that the chief judge is selected on the basis of seniority, ${ }^{60}$ not on the basis of administrative skill. Few distinguished professionals of the sort who become circuit judges are able to maintain through their mature years a zeal for attention to routine detail of the sort which characterizes much of the necessary quasi-judicial and administrative work. $^{\text {(it }}$ Furthermore, since most of the chief judges have attempted to maintain a full assignment of sittings, ${ }^{118}$

${ }^{64} 28$ U.S.C. $\$ 332$ (Ig64).

${ }^{65}$ Shafroth, supra note 33 , at $273,284-86$.

${ }^{66} 28$ U.S.C. $\$ 45$ (1964).

${ }^{67}$ Cf. Brennan, The Administrative Judge-The Key to Effective Court Management, 45 J. AM. Jud. Soc'y 272 (1962).

${ }^{68}$ See Shafroth, supra note 33 , at 284 . 
a drain on their energies impedes the basic work of the courts. It is not feasible to rely on the clerk of the court to perform these many chores. It is true that in many circuits the clerk is able to bear much responsibility, but the clerk is generally not a professional lawyer, and hence he cannot fittingly be assigned the quasi-judicial and major administrative burdens.

Will Shafroth has suggested that it is now time to create a new office for judicial administration. ${ }^{69}$ The suggestion seems eminently sound. A brief experimental run in, perhaps, one or two circuits ${ }^{\mathrm{T} 0}$ would be helpful in providing guidance as to the proper structure for the office, and it is to be hoped that other courts will soon be provided with similar relief so that the full corps of the nation's circuit judges can be devoted to the main work of the courts.

It also seems appropriate to suggest that the Shafroth proposal may be a little too modest in the functions assigned to the new officer. As presently conceived, he would be an administrative assistant to the chief judge, with a salary not to exceed that of the clerk. Such an office would be unlikely to attract a person of sufficient stature to perform or supervise the performance of all of the delegable duties listed above. Such an official must be a professional lawyer of skill and judgment, and he should be in a position to take over the responsibility for immediate supervision of the clerk. ${ }^{71}$ The officer therefore seems to merit higher salary than the clerk receives, an honorific title, and perhaps a more dignified position than that of servant to the chief judge. ${ }^{\text {?2 }}$

An officer selected under the conditions suggested could be expected to relieve the circuit judges of many burdens that may now restrict their productivity. Such an officer could perform a role not unlike that of United States commissioners and magistrates, who assist the district judges by making minor adjudicative decisions at the trial-court level. He could, at the same time, take full responsibility for the efficient operation of the court. An effective occupant of the office could conceivably in-

\footnotetext{
${ }^{60}$ Id. at 289 .

${ }^{70} \mathrm{He}$ selects the Second and the Fifth Circuits because of their size and because of the receptivity of the judges to the idea.

${ }^{71}$ It would be salutary if, occasionally, a district judge or a circuit judge could be induced to take the assignment. It must sometimes be the case that energetic men tire of the routine of their judicial duties and desire a change; some of these men might be very useful administrators. Their selection would enhance the stature of the office, and legislation could provide that judges taking the office would not have to accept a cut in salary. For analogous provisions for the Director of the Federal Judicial Center see 28 U.S.C. \$ 626 (Supp. III, I968).

${ }^{72}$ This last condition could be satisfied by making him appointable and removable by the council of the circuit.
} 
crease the productivity of the court more than would another judge. And, because he would not serve as an additional decider of cases, his presence would not contribute to the problems associated with an increase in the number of judges. The case for such a reform seems compelling.

It is difficult to estimate the impact on the productivity of the courts of more effective administration and of more adequate supporting personnel. ${ }^{73}$ It might be possible to increase the number of sittings significantly; perhaps each judge might sit another day or two per month. However, regardless of the savings of time, efficiency in decision making must ultimately rest in the practices of the individual judges, and such patterns are the hardest to change. Nevertheless, the gains to be achieved seem worthwhile even if ideal efficiency is not obtained.

\section{B. Abbreviating Deliberations}

The time of the appellate judges that is actually spent in hearing argument is too small a fraction of their total effort to make its compression an effective means of significantly increasing the rate of decision making. ${ }^{74}$ Moreover, if the oral argument is deprived of its vitality by excessive brevity or haste, an important opportunity to test and confirm opinion is lost, and the time required for decision may actually be increased.

There is a limit to the amount of argument that judges can prepare for and absorb in a given period of time. To think intensively and constructively about more than three or four serious problems in one day, when each requires the mastery of different background data, is a challenge which only the most able and energetic lawyers can surmount. Furthermore, opportunity must be left for study, deliberation, and conference. For these reasons the Fifth Circuit has limited argument to one full week per month, despite the pressure of a burgeoning backlog and increased delay. This seems to be about the maximum if the system is to operate effectively. ${ }^{75}$

It seems somewhat more likely that a slight increase in the rate of disposition can be wrought by revision of the opinionwriting practices. The traditional assumption was that each appeal deserved a full opinion which exposed the factors influencing the decision and expressed the values that were likely to be

${ }^{73}$ The recent addition of a second law clerk for each judge is a welcome step, but it will aggravate the recurring problem of lack of adequate secretarial help.

${ }^{74}$ Shafroth, supra note 33 , at 269 , reports a national average of 129 sittings per judgeship in I966. Allowing for vacancies, substitutes, and duty on the motion calendar, the average time spent in hearings is not likely to exceed 200 hours a year.

${ }^{75}$ Wright, The Overloaded Fifth Circuit: A Crisis in Judicial Administration, 42 Texas L. Rev. 949, 962 (1964). 
weighed in the making of future decisions. With increasing frequency courts of appeals have adopted the practice of deciding cases without opinion. ${ }^{70}$ In general, the practice seems to be reserved for frivolous or very marginal appeals. Although it may sometimes be appropriate to affirm on the opinion of the trial judge or the administrative agency, it is surely not acceptable practice to reverse without opinion. Even where the final judgment can be rendered on appeal so that no guidance to the trial judge is needed for his use on remand, it is too much a reproof to the judge to reverse his decision without stating reasons.

We should be reluctant to encourage the making of unexplained decisions. The same reasons which require that the decision be based on stable legal principle argue very strongly that the principle be stated, as a demonstration to the litigants and to the public that the court has done its job properly, as an aid to the future organic growth of the law, and as a means of selfdiscipline for the appellate judge.

This concern, however, does not dictate a need for full opinions in every case, nor, perhaps, in the bulk of the cases, which seldom present courts of appeals with the opportunity to exercise a law-making function. In a case having little significance for the future, the purpose of opinion writing can be fully served by a short opinion which describes the important facts and refers to a controlling principle which legitimates the result. The observable trend in this direction is a useful economy. Further economies might be effected if it could be established that per curiam opinions are appropriate to most federal appeals. ${ }^{77}$ It may well be that the format of the per curiam opinion less often tempts the writer to energy-consuming artistry; the authored opinion is likely to become a vehicle for memorializing the talents of the author.

Certain types of cases are especially appropriate for treatment by per curiam opinions. Most obvious are diversity and criminal cases. The substantive law governing diversity cases is state law with respect to which the law-making function of the circuit judges is of relatively little importance. ${ }^{78}$ Indeed, in such

\footnotetext{
${ }^{70}$ In I966, about one disposition in seven was made without opinion. Shafroth, supra note 33 , at $27 \mathrm{I}$; cf. Radin, The Requirement of Written Opinions, I8 CaLIF. L. Rev. 486 (1930) (advocating greater use of this practice). See generally Comment, Per Curiam Decisions of the Supreme Court: 1957 Term, 26 U. CHI. L. Rev. 279 (I959).

${ }^{77}$ In 1966 , Iog8 cases out of 4087 were decided in per curiam opinions, 3 Io out of 703 in the Fifth Circuit. Shafroth, supra note 33, at 27 I.

${ }^{78}$ But see Wright, supra note 40 , at $326-27$ (although the southern states have generally repudiated the state law decisions of the Fifth Circuit, the midwestern states have adopted much of the work of the Seventh Circuit).
} 
cases it is not unusual for a court of appeals to defer to the judgment of the district judge on a doubtful question of state law. ${ }^{79}$ Likewise, in most criminal matters and prisoner petitions there is seldom much to be said that will be of interest in the future, and many of the cases are frivolous. If the court is asked to reassess the evidence, it should write enough of an opinion to demonstrate that it has done its work, but there is little reason to gild the lily with a full statement of the social policy supporting the principle invoked. This is especially true because of the need for haste in deciding criminal appeals, which is required if the criminal law is to be effective in serving its purposes.

Of course, there are some cases of these types in which full opinions of circuit judges may be very useful. For example, in many states, almost all products liability litigation is removed to the federal courts. Unless the substantive issues are to be certified to the authoritative state courts, ${ }^{80}$ federal judges must decide them. ${ }^{81}$ Also, there may be significant issues of federal procedure arising in diversity cases. ${ }^{82}$ Similarly, there are exceptional criminal matters which present recurring problems requiring the creative efforts of the courts of appeals. With respect to these problems, full opinions may be quite useful.

The utility of the short, anonymous opinion is by no means limited to run-of-the-mill diversity and criminal cases. There are many appeals of all kinds which turn on very narrow issues of little or no general significance. Distinguished judges have suggested that as few as one-tenth of the appeals involve significant substantive issues. ${ }^{83}$ It is true, on the other hand, that the law-creating process should be closely related to the recordevaluating process which is the routine in the bulk of the cases. Too sharp a distinction between those cases which require fully reasoned analysis and those that do not could impair this relationship. Fuller analysis may sometimes reveal distinctions that are hidden by the quicker treatment. It may therefore be a wise conservatism to move more slowly in reducing the number of

\footnotetext{
${ }^{79}$ See generally C. WrIGHT, supra note 59, $\$ 58$, at 206.

${ }^{80}$ E.g., Green v. American Tobacco Co., 304 F.2d 70, 86 (5th Cir. 1963). The delays and other drawbacks of this practice are well illustrated by the subsequent history of the case. See Green v. American Tobacco Co., 391 F.2d 97 (5th Cir. 1968 ).

${ }^{81}$ However, the abstention doctrine may be available in some cases. Sec Meredith v. Winter Haven, 320 U.S. 228, 234-38 (1943); Note, Federal-Question Abstention: Justice Frankfurter's Doctrine in an Activist Era, 80 HARV. L. REV. 604 ( 1967 ).

${ }^{82}$ E.g., Sibbach v. Wilson \& Co., 3 I2 U.S. I (I940).

${ }^{83}$ Clark \& Trubek, The Creative Role of the Judge: Restraint and Frecdom in the Common Law Tradition, 7I Yale L.J. 255, 256 n.7 (1961).
} 
full opinions in those classes of cases in which the creative efforts of the courts of appeals are most useful.

In many instances a shorter opinion is not easier to write than a long one; indeed, there is folk wisdom to the contrary. But a reduction in the average length of opinions must permit some conservation in time, at least over the course of dealing with a large number of cases. Still, the extent to which such conservation would really permit a significant increase in the output of decisions by each judge may be doubted. The most important part of the task of decision, the process of conference and deliberation, is not affected. Hence, no more than a modest expectation is justified.

\section{Panel Size}

The most direct method of improving efficiency in the deployment of the circuit judges would be to reduce the number sitting on each decision. Courts of appeals have customarily sat in panels of three judges, ${ }^{84}$ but on occasion one member of a panel has been unavailable and a decision was nevertheless rendered. No serious consequences appear to have followed from such events. Perhaps this indicates that thought should be given to more general reductions in the size of panels.

Several considerations detract from the appeal of the twojudge court as a device to promote efficiency. With one fewer perspective from which to view the cases and one fewer avenue of communication open between counsel and the court, the judges are disadvantaged in their effort to gain a full understanding of the issues presented. Heavier reliance would be placed on the quality of the judges' law clerks and on the skill of counsel.

In addition, the decision of the two-judge court would be more personal and less institutional than a decision of a threejudge court. Not much is known about the differences in the interpersonal relations within dyads and triads, ${ }^{85}$ but those with experience at bridge, tennis doubles, and family finances must be suspicious of the consequences of having only two decision makers. It is not unlikely that the judge with the greater exper-

\footnotetext{
${ }^{84}$ It is not clear whether two-judge panels are permitted by the statute. Compare 28 U.S.C. $\$ 46($ b) (Ig64) ("the court may authorize the hearing . . of cases . . by separate divisions, each consisting of three judges") with 28 U.S.C. $\$ 46$ (c) (I964) (" $[c]$ ases . . . shall be heard . . . by a . . . division of not more than three judges ...").

${ }^{85}$ Recent efforts of social psychologists to develop laboratory analyses of such relationships are not particularly probative of any of the possible hypotheses. See, e.g., Raven \& Eachus, Cooperation and Competition in Means-Interdependent Triads, 67 J. Abnormal \& Soctal Psych. 307 (1963). The best work on the subject seems to be based on the intuitions of a German scholar who died a half century ago. See The Sociology of Georg Simmei i 18-69 (K. Wolff ed. I950).
} 
tise or the more adamant convictions would tend to dominate the panel more than in the three-judge setting, where the other two judges can combine to form a majority. Thus a wise advocate would more often tailor his arguments to the personal idiosyncrasies of the individual judges, and personal value judgments would become a more usual part of the process. For this reason, and because a smaller court is less likely to represent a sound consensus about the values expressed in the national law, the use of two-judge panels would result in less stable doctrine than under present practice. ${ }^{86}$ There would therefore be a great increase in the need for further institutional restraints, and the judges would have to devote a great deal more care and attention to petitions for en banc rehearings. ${ }^{87}$

In addition, there is the prospect of a split between the judges. It is hard to tell how frequently this might happen. Dissents in the courts of appeals are relatively rare. A check indicates that they occur in about seven percent of the cases, ${ }^{88}$ but this datum is probably misleading; it seems not unlikely that the suppressed dissent is a more common phenomenon in an intermediate appellate court than in a court of last resort, where a telling dissent is more likely to be resurrected in the future. For this reason, we cannot know how often the problem of a split is likely to arise.

A split might be resolved by simply affirming the decision below, or by denying relief in original proceedings. ${ }^{80}$ It would seem more appropriate, however, to break the deadlock. A third judge might be brought in, but he would be put in a sensitive position in which he would bear personal responsibility for the decision, thereby impairing the effectiveness of the process in diffusing responsibility. An alternative might be to bring the split case before three additional judges rather than one, but this procedure would be so inefficient that it would defeat the purpose of the two-judge court.

\footnotetext{
${ }^{86}$ All of the problems so far discussed apply with much greater force to onejudge panels. Furthermore, a one-judge court with power to reverse would be a serious affront to the status of the trial court, since the institutional assumption would seem to be that the reviewing judge is sufficiently more capable than the trial judge that he can improve on the latter's work despite his remoteness from the evidence and the parties.

87 The use of en banc proceedings to maintain stable doctrine will be discussed below. See pp. 580-85 infra.

${ }^{88}$ Goldman, Conflict and Consensus in the United States Courts of Appeals, 1968 WIs. L. REv. 46r, 464. This study reveals a considerable variation in the rate of dissent, from a high of $15.5 \%$ in the District of Columbia Circuit to a low of $2.8 \%$ in the Sixth Circuit. The study is based on 1962-1964 cases.

${ }^{89}$ This procedure is generally employed by the Supreme Court in comparable situations. See 28 U.S.C. § 2 rog ( 1964 ).
} 
A careful selection of the cases assigned to two-judge courts might minimize the risk of a split, but a particularized process of selection seems unlikely to succeed. The decision to categorize a particular case as one not likely to engender a dissent seems too close to a decision on the merits to permit delegation to a nonjudicial officer of the court. ${ }^{90}$ On the other hand, if a judge is to undertake the assignment, his determination of how many judges should hear the case would so prolong and encumber the process of decision that a net saving in time again seems unlikely.

In any event, less than one-third of the energy devoted to cases by three-judge courts would be spared by the innovation. The opinion-writing burden would be shared by the two judges instead of three, and the cumbersome procedure for resolving splits would eat into the time saved. When the intangible consequences of the change are taken into account, including the risk of fundamental change in the character of the decisional process, it would seem that a reduction in panel size is an innovation which should be adopted only under considerable duress of congestion. However, the two-judge court does seem superior to a big backlog, with all its deleterious consequences to the quality of the process. Perhaps, therefore, courts of appeals confronted with grave and immediate problems of congestion should be authorized to reduce panel size in order to keep control of their dockets. Before resorting to such an innovation, however, we should consider the various means available for obtaining additional judges in special situations.

\section{Senior Judges, Visiting Judges, and District Judges}

Senior judges are those who have retired from regular active service but who are eligible to act on a voluntary basis. ${ }^{91}$ They do not occupy places on the court's table of organization; hence, in a sense, their servicis arc a possible bonus in meeting the congestion problem. Because they do not generally sit on en banc proceedings,"' they ease the workload withou complicating the problem of coordinating the law of the circuit. But, for the same reason their views may be less representative of the consensus of the court than those of the active circuit judges, so that their service does introduce an element of instability.

There is probably very little that can be done to increase the

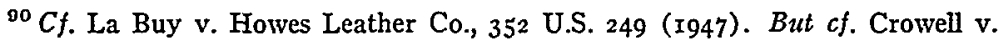
Benson, 285 U.S. 22 (I932).

${ }^{01} 28$ U.S.C. $\$ \$ 294$ (b), 294 (d), 37 I (b) (I964).

${ }^{02}$ They participate only in rehearings of cases submitted to them. 28 U.S.C. $\S 46$ (c) $(1964)$.
} 
[Vol. $82: 542$

availability of this source of manpower. Given the nature of the office of senior judge, it seems unlikely that inducements could be provided which would make many of these judges more available for service than there now are. ${ }^{93} \mathrm{~A}$ few more senior judgeships might be created by the adoption of a mandatory retirement plan. ${ }^{94}$ This, however, would raise a constitutional problem, and it involves an array of considerations about the extent to which such a plan would improve or impair the quality of the federal judiciary. ${ }^{95}$ These considerations so predominate that the decision should not be controlled by the congestion problem in the court of appeals.

More promising is the prospect of increasing the availability of visiting judges. The Judicial Code presently authorizes the Chief Justice to assign additional judges to a court of appeals upon presentation of a certificate of necessity by the chief judge or the circuit Justice of a circuit in which a need arises and a grant of consent by the chief judge of the court from which the assignment is to be made. ${ }^{\text {n }}$ Through the use of this provision, the Fifth Circuit was able to secure additional manpower during the years of its greatest need. In total, however, the amount of work performed by visiting judges has been small, and in 1966 it was less than three percent of the total sittings. ${ }^{n T}$ Some improvement of this record could be made.

The present program of intercircuit transfer is administered by the Advisory Committee on Intercircuit Assignment of the Judicial Conference. The Committee lacks power to require transfers; it must rely on voluntary undertakings by individual judges who have been willing to answer the call, many without relief from their regular duties. ${ }^{98}$ Some chief judges have been reluctant to permit volunteers to serve in this way because they have felt that their own courts were not adequately supplied with personnel. The system dates from an earlier time, when there was a fear that the procedure might be abused by judges junketing at the expense of the United States." The Advisory Com-

\footnotetext{
${ }^{93}$ Their retirement in the first place was voluntary, and by statute they are entitled to full pay for the rest of their lives. 28 U.S.C. $\$ 27$ I (b) (1964).

${ }^{94}$ There were six active circuit judges over the age of 70 in 1967 . Shafroth, supra note 33 , at 275 .

${ }^{95}$ See generally Major, Why Not Mandatory Retirement for Federal Judges?, 52 A.B.A.J. 29 (1966).

9628 U.S.C. $\$ \S 29 \mathrm{r}(\mathrm{a}), 295$ ( 1964$)$.

${ }^{97}$ Shafroth, supra note 33 , at 276 .

${ }^{98}$ At almost every session of the Judicial Conference the Committee points out the need for more help. See, e.g., ig66 Report of the Proceedings of tile JUdicial Conference of the United States I2, 43.

${ }^{99}$ This pertains only to the requirement of the consent of the chief judge of the transferor court. The permission of the chief judge of the transferee court
} 
mittee has been very effective in preventing any self-dealing of this sort, but it has not performed the service of equalizing the workload of circuit judges on a national basis.

It is in the national interest that the pressure of congestion be as widely distributed as possible. The present system cannot accomplish this. The chief judges, who feel responsible for the quality of their own courts and who find it difficult to certify that their colleagues are underemployed, can hardly be blamed, and it is understandable that judges have not hastened to volunteer. It seems desirable that the influence of national judicial administration be more broadly felt. The Director of the Administrative Office might be instructed to remain informed on the relative state of dockets and workloads and to recommend personnel levies to be imposed by the Chief Justice on those courts which seem least pressed to meet their obligations. This will require some sophistication in appraising statistics, and care will have to be taken to see that no individual judge is unfairly burdened with more than his share of unwelcome temporary duty. But with these precautions an important contribution to the problem can be made by efficient deployment of personnel.

A change from a wholly voluntary system for intercircuit transfers would also permit the transferee court to assign visiting judges to cases in which their services could best be used. Because a visitor is not a regular member of the court and does not sit on en banc proceedings, he introduces an element of instability to the panel on which he serves. For this reason it would seem appropriate to try to use visiting manpower in diversity and criminal cases, where the law-making function of the court is least likely to be invoked. Because this kind of duty is often least welcome, the transferee court cannot now make such assignments without imperiling the supply of volunteers.

Another source of extra manpower is the corps of federal trial judges. They were responsible for almost nine percent of the appellate sittings from r96I to I966, including twenty percent of those in the Fifth Circuit. ${ }^{100}$ Their service is explicitly authorized by statute, and may be obtained either by means of intercircuit or intracircuit transfer. ${ }^{101}$

The use of district judges does present a special problem with respect to its impact on the quality of review, since the qualities that make a good trial judge are somewhat different from those which make a good appellate judge. Furthermore, was required in order to prevent court packing by the Chief Justice. Hearings on S. 2655 Before a Subcomm. of the Senate Comm. on the Judiciary, 77th Cong., 2d Sess. I7 (1942) (statement of George M. Morris).

${ }^{100}$ Shafroth, supra note 33 , at 276 .

${ }^{101} 28$ U.S.C. $\S \S 292(a), 292(\mathrm{c}), 293(\mathrm{a}), 295(x 964)$. 
few district judges are supported by law clerks of the same degree of intellectual accomplishment as those frequently employed by circuit judges. Not too much, however, can be made of these differences. It is likely that the qualities required for an adequate performance on a court of appeals are more common than those required for an adequate performance on a district court. It is also true that the specialized skills of the district judges, to the extent that they exist, can offer a very useful dimension to the deliberations of the courts of appeals. In diversity cases, the dominant values are supposed to be those employed by state courts; thus a local district judge would be a valuable member of the reviewing panel in such cases. In criminal litigation, the reviewing court is rarely required to formulate the national policy, which is nearly always clear; rather the task of review is largely directed at a detached reevaluation of the record. It therefore might be useful to assign a district judge to every panel engaged in reviewing a criminal conviction or a prisoner petition. Certainly, this could economize significantly the time and the energy of circuit judges. The only serious difficulty with this proposal is the limited availability of district judges. Their dockets are often more heavily burdened than those of the courts of appeals. There is, however, a significant supply of district court manpower in every circuit except that serving the District of Columbia. ${ }^{102}$ Rarely has this source been as fully exploited as it should be. ${ }^{103}$ Indeed, it might be an appropriate response to the problem of appellate congestion to plan for a modest amount of slack in some district courts in each circuit.

In summary, a wide range of improvements in administration offer some promise of relief. To some extent the judges can do a better job of husbanding their energies without excessive peril to the quality of the process. To some extent, even greater economies can be obtained by more vigorous administration of judicial personnel with respect to the size and composition of panels. To some extent, greater use can be made of judges not regularly

\footnotetext{
${ }^{102}$ Fifteen district judges are assigned to the District of Columbia; in 1966 they averaged over 54 trials each. Comparable averages are D. Del. $x$, D. Hawaii $\mathrm{r}_{3}$, D. Alas. $\mathrm{r}_{4}$, D.S. Dak. $\mathrm{r}_{4}$, S.D. Ill. I4, D.N.H. I6, E.D. Ill. $\mathrm{I}_{7}$, D. Mont. 21, N.D. Ohio I8. See ig66 ANnuad Report 197-99, 262-64.

${ }^{103}$ Arguably, all available trial judge manpower should be applied to trial court dockets, many of which are in deplorable condition. Some interdistrict transfers are accomplished, and this is highly desirable. But the work of the trial judge requires larger blocks of time for effective manpower utilization than does the work of the circuit judge. Appellate work is therefore more amenable to disposition by transient judges.
} 
sitting on the circuit. One who is less cautious about the need to preserve the basic quality of the existing process might well conclude that more sweeping changes could be made in these same directions. It seems clear, however, that there are fairly low limits to what may be accomplished toward improving the rate of dispositions by each judgeship without sacrificing the qualities of the process of review which justify its existence.

\section{The Right to Review and Abuse of the Process}

\section{A. Restricting the Scope of Review}

Appellate courts can protect the rights of litigants only at some risk of eroding those rights, and perhaps others, with prolonged and costly dispute. If a case is not too difficult and neither party is dilatory, an appeal can be decided within six months of trial. If there is an extraordinary need for haste, the process can be accelerated, but extensions beyond the six-month period must be regarded as normal, even if the backlogs on some federal appellate dockets are disregarded. ${ }^{104}$ Furthermore, appeals are expensive. It is a very simple appeal which does not result in the losing party's being assessed costs of five hundred dollars. In a big case, the costs may be many times that figure. ${ }^{105}$ Attorneys' fees often exceed all other costs combined.

In addition to these economic costs, the appellate court must bear in mind the need to preserve the dignity and significance of the trial court proceeding. Indiscriminate use of the power of review tends to deprive the primary decision of its intended effect of bringing repose to the dispute. Combatants are encouraged to save their heavy artillery to use in the reviewing court and to treat the primary trial as an opening skirmish.

These costs of the process are permanent features. The need to weigh them against the advantages to be gained by the exercise of the power of review is present in every case. To be effective as a restraint on the power of the trial judge, review must be readily available, but it cannot work to best advantage unless there is abundant time for counseling and deliberation. The more careful the job done by the appellate court in protecting the rights of the litigants before it, the greater the expense in money and delay imposed upon them, and the greater the deterrence to future litigants who may wish to seek similar relief. All this inner

\footnotetext{
${ }^{104}$ In 1967 the median lapse between filing a complete record and final disposition was 8.8 months. 1967 ANNUAL REPORT I9O.

${ }^{105}$ Some years ago, the cost of the average appeal to the New York Court of Appeals was estimated at $\$ 1200$. INSTItUTE of Judicial Administratron, Cost of Apreals Study 35 (prelim. draft I954).
} 
stress requires delicacy in the operation. To recognize the point at which the burdens imposed by additional attention to the pleas of appellants will outweigh the benefits that might be obtained through further operation of the process is not easy, since it requires the weighing of imponderables, including the limit of the court's own wisdom.

To help maintain a proper balance, statutes, precedents, and rules of court contain principles of restraint which operate on the appellate courts in the exercise of their power. The collective thrust of these principles is that an appellate court will not interfere except to consider a question which is amenable to its deliberative method and important enough to justify its use, and to enforce such considered decisions; even then, the appellate court will not intercede on behalf of a litigant who has not cooperated sufficiently in the effort to minimize the cost and delay of the process. There seems to be an increasing relaxation in some of these principles, including the doctrines of ripeness ${ }^{100}$ and mootness ${ }^{107}$ and the final judgment rule, ${ }^{108}$ and this trend has brought a steady enlargement of the impact of review on the primary decision makers and a corresponding enlargement in the business of the appellate courts.

Halting or reversing this trend would lessen somewhat the burden on the courts of appeals, and at some point it must be halted, for the returns from review will be overbalanced by the costs. Reasonable men may surely differ as to when this point will be reached; indeed, some assert that it has already been passed. ${ }^{109}$ It is a premise of this article, however, that the trend toward greater review is welcome and that the critical point is not so near that the trend should be halted. The growth of review reflects the growth of law as an aspect of American life, designed to protect citizens from personalized applications of official power. It is also responsive to our rising expectations for law as an instrument of social reform since any hope for effective legislation is dependent on the internal discipline of the law enforcement machinery. The costs of review and the crisis of congestion have not reached the point where we should stunt this growth as a protective measure.

${ }^{106}$ See, e.g., Abbott Laboratories v. Gardner, 387 U.S. 136 (1967); Toilet Goods Ass'n v. Gardner, 387 U.S. I58 (I967) ; Gardner v. Toilet Goods Ass'n, 387 U.S. 167 ( 1967 ).

${ }^{107}$ See Sibron v. New York, 392 U.S. 40, 50-58 (I968).

${ }^{108}$ See generally Frank, Requiem for the Final Judgment Rule, 45 TExas L. REV. 292 (I966).

${ }^{109}$ See Green, Jury Trial and Mr. Justice Black, 65 YALE L.J. 482 (1956); Wright, The Doubtful Omniscience of Appellate Courts, $4 \mathrm{I}$ MiNN. L. REv. 75I (I957). 


\section{B. Taxation of Costs as a Deterrent to Abuse in Civil Cases}

In light of the present congestion problem, there is no reason to tolerate litigants who appeal only in desperation. At present, the only deterrents systematically imposed are the risks of liability for costs and interest. ${ }^{110}$ There is usually no risk that the unsuccessful appellant will be taxed for the appellee's attorneys' fees. ${ }^{111}$ Although the English and some continental legal systems allow the taxation of modest attorneys' fees to the party prevailing on appeal, ${ }^{112}$ this procedure seems too inconsistent with our ideals of equal treatment for poor litigants ${ }^{113}$ and too likely to deter meritorious appeals to be acceptable.

A more selective approach, which would impose sanctions only against frivolous appeals, seems more attractive. Two approaches are suggested by present legislation. One old federal statute, which has never been used to effect, authorizes imposition of costs on the attorney who so "multiplies the proceedings in any case as to increase costs unreasonably and vexatiously." 114 Vigorous enforcement of this provision is surely unattainable ${ }^{115}$ and undesirable. While counsel has a responsibility to prevent abuse of process, ${ }^{116}$ he is already subject to considerable stress in serving conflicting loyalties to courts and clients; it would be most unfair and probably ineffective to attempt to make the risk of substantial personal economic loss a factor influencing his behavior. Inasmuch as the ultimate decision to appeal is the client's in any event, it seems much more reasonable to address the sanctions and the warnings to the pocketbook of the litigant.

There has been a statutory basis for sanctions against frivolous appellants since the original Judiciary Act of $x 789,{ }^{117}$ but it is so poorly drafted that it is quite uncertain in its application, in the sanctions it provides, and in its administration. Sanctions,

${ }^{110} 28$ U.S.C. $\$ \S 1920,196$ I (1964).

111 Fleischmann Distilling Corp. v. Maier Brewing Co., 386 U.S. 714 (1967).

${ }^{112}$ See Clark, The Evershed Report and English Procedural Reform, 29 N.Y. U.L. Rev. I046, I056-57 (1954); Kaplan, Civil Procedure-Reflections on the Comparison of Systems, 9 Buffalo L. Rev. 409, $4 \mathrm{I} 4$ (r960).

${ }^{113}$ See Duniway, The Poor Man in the Federal Courts, I8 Stan. L. Rev. I270 (Ig66).

11428 U.S.C. $\&$ I927 (I964).

${ }^{115}$ In no reported case has this statute ever been invoked by an appellate court to punish a frivolous appeal. The only reported case from any court is Toledo Metal Wheel Co. v. Foyer Bros. \& Co., 223 F. 350 (6th Cir. 1915). The sin was excessive cross examination; the penalty, $\$ 75.24$.

${ }^{116}$ ABa Canons of Professional Ethics No. 30. For a discussion of the efficacy of this restraint see Thode, The Ethical Standard for the Advocate, 39 Texas L. Rev. 575, 589-92 (1961).

11728 U.S.C. $\$$ I9I2 ( 1964$)$ (originally enacted as Judiciary Act of 1789 , ch. 20, § 22, I Stat. 73). 
including "damages for delay" and double costs, are authorized whenever a judgment is affirmed, and the sweep of the statute seems to embarrass the court invoking it. Despite occasional threats that the statute would be more stringently enforced in the future, ${ }^{118}$ only about two dozen appellants have been assessed in the last seventy-five years. ${ }^{110}$ On a few of these occasions, the court was willing to impose the sanction without discussion, ${ }^{120}$ but more often it has been deemed necessary to give some reason for singling out a particular litigant. ${ }^{121}$ Such reasons have not been easily supplied. In several cases, courts have perhaps unwisely withheld sanctions by applying a sentimental, subjective test which caused them to endorse the good intentions of appellant's counsel in urging an appeal without merit. ${ }^{122}$ Reluctance to invoke the statute has also been exhibited in cases in which artificial limitations are imposed on the statutory discretion, such as the rule that no sanctions can be imposed against a frivolous challenge to jurisdiction. ${ }^{123}$

The spectacle of erratic application supports the belief that the present statute is worthless as a restraint on frivolous appeals. Yet it is unlikely that even an artistically drafted statute providing modest, reasonably proportioned sanctions would have an impact on the flow of appeals. Part of the problem lies in the fact that civil litigants who have invested heavily in time, money, and emotion are not likely to settle for disappointing results at trial if there is any prospect that the decision might be reversed with a slight additional investment in an appeal. Such expectations are confirmed by our experience with the zestless and ineffectual use of sanctions by district courts in their protection of the discovery process from frivolous abuse, ${ }^{124}$ and also by the ineffectiveness of the use of costs as sanctions to deter plaintiffs from the use of federal courts in actions not actually involving

${ }^{118}$ See, e.g., Whitney v. Cook, 99 U.S. 607 (I878); United States ex rel. Soda v. Montgomery, 269 F.2d 752 (3d Cir. I959).

${ }^{119}$ E.g., Roe v. Kansas ex rel. Smith, 278 U.S. I9I (I929); South E. Atl. Shipping Ltd. v. Garnac Grain Co., 356 F.2d 189 (2d Cir. 1966); Dunscombe v. Sayle, 340 F.2d 3II (5th Cir. I965).

${ }^{120}$ E.g., Nelson v. Flint, I66 U.S. 276 (1897); Ginsburg v. Stern, 295 F.2d 698 (3d Cir. I96I). In the latter case, the court also ordered the appellant's brief stricken from the records of the court.

${ }^{121}$ E.g., Roe v. Kansas ex rel. Smith, 278 U.S. Igr (I929); Commercial Wholesalers, Inc. v. Investors Commercial Corp., I72 F.2d 800 (9th Cir. 1949).

${ }^{122}$ E.g., United States Fidelity \& Guar. Co. v. English, 272 F.2d 187 (5th Cir. I959).

${ }^{123}$ E.g., Gregory Consol. Mining Co. v. Starr, 14I U.S. 222 (1891). But cf. Slaker v. O'Connor, 278 U.S. I 88 (1929).

${ }^{124}$ See Finman, The Request for Admissions in Federal Civil Procedure, 71 YALE L.J. 37 I (I962); Rosenberg, Sanctions To Effectuate Pretrial Discovery, 58 CoLuM. L. Rev. 480 (I958). 
the proper jurisdictional amount. ${ }^{125}$ It is to be concluded that revision of the statute may be worthwhile for its own sake, but not as a significant remedy to the problem of congestion.

\section{Screening of Appeals in Civil Cases}

If we cannot rely on parties or their counsel to forbear from urging spurious appeals, we may find need to make the decision for restraint in their behalf. Such a procedure is contemplated, for example, in rule 5 of the Rules of the First Circuit, which provides that "[a]t any time ... the court may dismiss the appeal or affirm the judgment below if the court lacks jurisdiction over the appeal or if it shall clearly appear that the appeal presents no substantial question." A program of more active use of this sort of rule might suggest itself as a solution to the congestion problem, but it would in fact be unwise to encourage greater use simply for the purpose of conserving judicial energies. ${ }^{126}$ This is so because of the energy required to consider whether an appeal is worthy of judicial consideration. Only very rarely will a case reveal on its face that it is motivated by delay or otherwise frivolous. Once the effort is made to think through the contentions of the parties and to make an earnest effort to evaluate them, the court is sufficiently committed that there is very little economy in avoiding plenary disposition. The time saved from oral argument could be quickly offset by the time spent in deliberation on the preliminary motion for summary affirmance. If the purpose is to save the writing of the opinion, this might be done, to the extent that it is advisable, without any prehearing screening. Thus, while the summary affirmance may be a useful device for giving calendar preference to easy cases which can be decided without delay, it is not a prospective source of significant economies of judicial time.

A comparable device which would be subject to the same objections, but which might be more effective to control congestion, would be the enlargement of the requirement of leave to appeal. This would differ from the summary affirmance in shifting the burden of persuasion; the appellant would be affirmatively required to justify his use of the appellate process. Such a requirement is presently a feature of interlocutory appeals and prisoner petitions within the federal system. ${ }^{12 \pi}$ It is a general

${ }^{125}$ See ALI STUDY, supra note $40, \S$ I30I.

${ }^{120}$ Of course, where the appeal is patently frivolous an early dismissal or affirmance may represent a substantial saving for the parties. The First Circuit experience has been that the rule is successfully invoked only four or five times a year, out of about 275 appeals. Interview with Chief Judge Aldrich, in Boston, Mass., Nov. 26, 1968. E.g., Magnesium Casting Co. v. Hoban, 4or F.2d 5 I6 (Ist Cir. rg68).

${ }^{127} 28$ U.S.C. $\$ \S 1292(\mathrm{~b}), 2253$ (1964). 
feature of appellate review in the courts of Virginia and West Virginia. ${ }^{128}$

The procedure may also be suggestive of the certiorari practice of the Supreme Court, but this comparison is inappropriate because of the different roles of the courts. The certiorari practice, inaugurated with the Evarts Act ${ }^{120}$ and enlarged by the Act of $1925{ }^{130}$ was made possible by the creation of the courts of appeals to perform the basic work of review. Thus, the courts of appeals remain responsible for reviewing the substantiality of the evidence and the propriety of the fact-finding process, while the Supreme Court is expected to decide only questions of great public importance. ${ }^{131}$ It might be possible to identify a few classes of cases in which this distinction is less clear. In cases under the Social Security Act ${ }^{132}$ and in cases arising under the Longshoremen's and Harbor Workers' Compensation Act, ${ }^{133}$ for example, there has been an administrative finding reviewed by a district judge when the case reaches the court of appeals. Conceivably, some energy might be conserved if review in such cases were restricted to the more abstract considerations pertaining to the accuracy of the legal principles invoked in support of decisions. The effect, however, would be to place greater reliance on the administrator and district judge and deprive litigants in such cases of the kind of institutionalized, impersonal review of the evidence which they have come to expect. Such a deprivation does not seem justified by the limited saving that would be accomplished.

Alternatively, a similar restriction might be imposed on review in diversity litigation because of the relative unimportance of the role of the courts of appeals in such cases. It must be observed, however, that the role would be almost entirely eliminated if the only diversity cases which were reviewed were those which presented interesting legal issues on which the authoritative voice of the courts of appeals should be heard. The need in diversity cases is often a need for a review of the sufficiency of the evidence and the adequacy of the procedure; these questions are seldom disposable on the basis of cursory screening. Moreover, qualifying the right to review in diversity cases would create an unfavorable contrast with the practice in state courts. ${ }^{134}$

\footnotetext{
${ }^{128}$ VA. Code ANn. $\$ 8-476$ (1950); W. VA. Code ANN. \$ 58-5-10 (I966).

${ }^{129}$ Circuit Court of Appeals Act of $189 \mathrm{r}$, ch. 57x, $\$ 6,26$ Stat. 828 .

130 Judiciary Act of 1925, ch. 229, $\$ 237,43$ Stat. 936.

${ }^{131}$ F. Frankfurter \& J. LaNDIS, supra note 7 , at $255-86$.

${ }^{1: 32}$ Ch. 53I, 49 Stat. 620 (1935) (codified in scattered sections of 42 U.S.C.).

${ }^{13: 3} \mathrm{Ch} .509,44$ Stat. 1424 (1927), as amended, 33 U.S.C. \$\$ 901-50 (1964).

${ }^{1: 34}$ In addition, there may be an argument that the right to review under state law is a substantive right which the federal courts must respect.
} 
The saving achieved by screening might be enhanced if the screening decision could be delegated to someone other than the panel of circuit judges who would hear cases passing the screening process. A difficulty with such a scheme is the resultant diffusion of responsibility. Differences between the regular panel and the screening authority about what sorts of contentions should be regarded as substantial and worthy of review, and which should be regarded as insubstantial, would create embarrassment, confusion, and uncertainty. There is also the more substantial difficulty that such a scheme might operate as an additional level of review. And the burden of delay and expense would fall on worthy and unworthy litigants alike. The similarity between the decision to review and the decision on the merits would require a fairly full presentation to the screening authority.

It would be inappropriate, and quite possibly unconstitutional, to delegate the responsibility for a final screening decision to a nonjudicial officer of the court. It might be possible to use the same district judge who decided the case at trial as a screening authority, by requiring his permission to appeal, but the likely existence of preconceptions is a fatal difficulty in such a system of screening. Although there is some experience in England with systems which permit a lower court to participate in the decision as to the availability of review, this role is not permitted, even in England, of one-judge courts. ${ }^{135}$ The operation of such a system would give rise to the frequent use, or attempted use, of mandamus to compel leave to appeal, and would produce dissatisfactions of the sort engendered by the occasional practice of a century ago, when district judges were sometimes assigned to duty on the bench of circuit courts where they might find themselves called upon to review, singlehandedly, one of their own judgments. While we have been content to permit the district judge to control access to review under the Interlocutory Appeals Act of $195^{8}$, he is there empowered only to delay, never to prevent, review of his decision. ${ }^{136}$

More plausible would be the delegation of the screening decision to a single member of the panel of circuit judges. This sort of delegation would be less objectionable than leaving the matter in the hands of the district judge. Inasmuch as the circuit judge would be authorized only to affirm the judgment below, there is no longer the risk of wholly personal justice; he cannot singlehandedly override the rights of litigants. ${ }^{13 \pi}$

\footnotetext{
${ }^{133 .}$ D. Karden, Appeclate Courts in the United States and Engrand i2 I ( 1963$)$.

${ }^{130} 28$ U.S.C. $\$ 1292\left(\right.$ b) $\left(196_{4}\right)$.

${ }^{137}$ In this important respect, one-judge screening differs from the proposal for a one-judge panel to pass on the merits. See note 86 supra.
} 
[Vol. 82:542

Nevertheless, there will inevitably be cases in which the individual values of the circuit judge appear to have dominated the result. Also, some cumbersome procedure is likely to result as an outlet is sought for efforts to obtain panel overruling of individual screening decisions. Furthermore, there may be concern that the change in the character of the appeal from a right to something resembling an act of grace would alter the relationship between the trial judge and the litigants before him in a subtle and unwelcome way. Imperiled as his sense of proportion is by the importance of his office, a change that would increase this peril should be taken with the greatest reluctance. On balance, the risks and costs of enlarging the screening apparatus for civil appeals seem to exceed the visible benefits.

\section{The Right To Appeal in Criminal Cases}

The attractions of screening are greatest in their possible application to criminal cases, which are a substantial source of the present congestion problem. The Criminal Justice Act of I964 ${ }^{138}$ has yet to run its full course in stimulating this trend by supplying free transcripts and counsel to indigents. It is likely that the rate of appeal will continue to increase as more indigents, who constitute the bulk of the accused, become aware that they have nothing to fear from an appeal and that they may gain, if not a reversal, at least a release on bail during the pendency of the appeal. ${ }^{139}$ The District of Columbia has pioneered the federal procedural developments in the last decade, and it may be observed that more than one prosecution in six commenced in the District now reaches the court of appeals. ${ }^{\mathbf{1 4 0}}$ If that rate were to become general, the number of criminal appeals would reach 5200 per year, which is more than triple the present rate.

It is probably constitutionally impossible to deter appeals by providing effective punishment for those who abuse the process. ${ }^{141}$

\footnotetext{
${ }^{138}$ I8 U.S.C. $\S 3006 \mathrm{~A}$ (1964).

${ }^{139}$ Under Rule V of the Criminal Appeals Rules, 292 U.S. 66I (1934), stay of execution pending appeal was automatic. The present FED. R. CRIM. P. 38 requires that the appellant make bail in order to secure a stay. He is entitled to bail unless the court finds that there is no condition of release which will reasonably ensure against flight or danger to the community. I8 U.S.C. \& 3148 (1964).

${ }^{140}$ In 1967 there were 1455 prosecutions commenced in the District and 254 criminal appeals filed. 1967 ANNUAL REPORT 180, 243.

${ }^{141}$ Since most criminal appellants are indigents, to threaten frivolous appellants with financial penalties would either discriminate unfairly against the rare convict who could pay or would run afoul of the spirit of Griffin v. Illinois, 351 U.S. 12 (1956) (requiring state to give free transcripts to indigents), and Rinaldi v. Yaeger,
} 
In any event, it seems unwise and unfair to do so. Those who find themselves in the unfortunate situation of being convicts can hardly be expected to strike a fine, rational balance in making a decision about the appeal. No deterrence that would be effective would be reasonably proportioned to the gravity of the offense. The frivolous criminal appellant is merely trespassing lightly on the time of public officials; important as it is to conserve the judges' time, this can hardly be treated as a heinous offense worthy of severe punishment.

Moreover, the appellant might have a constitutional right to be heard. In Douglas v. California ${ }^{142}$ the Court directed that an attorney be appointed for an indigent despite a judicial determination that the appeal would be frivolous. In Lane $v$. Broven, ${ }^{143}$ Indiana was required to provide a transcript to an indigent whose public defender had refused to appeal because he deemed the issues presented to be frivolous. Most recently, in Anders v. California, ${ }^{1 \pm 4}$ the Court rejected appointed counsel's determination that an appeal was without merit, holding that counsel was obliged to brief all points to the end of demonstrating that they were not arguable. These holdings, however, do not go so far as to establish that a single circuit judge could not serve to sift out frivolous criminal appeals. The Constitution may well require ventilation of every possible appellate contention, but it is hard to find a need to give specious contentions the same quantity of judicial deliberation as worthy ones. Furthermore, there is precedent for one-judge screening to be found in the prisoner petition practice. ${ }^{145}$

The reasons for not employing a screening system in civil cases also apply to criminal cases. There is an unwelcome increase in the impact of the personality of the individual circuit judge. The screening system might operate to delay consideration of meritorious appeals and would create a separate process which might itself be subjected to some kind of review. And the personal power of the district judge would be somewhat enhanced. But there are two considerations peculiar to the criminal process which might be thought to tilt the scales of judgment in favor of screening.

One is the right to a speedy trial. While the constitutional as-

\footnotetext{
384 U.S. 305 (Ig66) (prohibiting state from deducting cost of transcript from prison wages).

142372 U.S. 353 (1963).

143372 U.S. 477 (1963).

144386 U.S. 738 ( 1967 ).

14528 U.S.C. $\$ 2253(1964)$. Note also that in Virginia and West Virginia there is no appeal as of right from a felony conviction. See pp. 57I-72 supra.
} 
surance applies only to trial court proceedings, ${ }^{140}$ the reasons for its existence are not altogether inapplicable to delay caused by the appellate process. The affairs of the accused and of his family are kept in suspension during the period of pendency of the appeal. Moreover, the purposes of the criminal law are significantly impaired. Delay in punishment dilutes deterrence. It tends to postpone removal of the offender from the streets. Even rehabilitation may be misserved by a long delay between the crime and the beginning of treatment.

The second consideration is the effect of burgeoning criminal litigation on the quality of the appellate process. The courts of appeals are in danger of becoming dominated by their role in the administration of the criminal law. With respect to the number of filings, criminal appeals and prisoner petitions constituted twentythree percent of the courts' business in $1960 ;{ }^{147}$ in 1967 , the comparable figure was thirty-eight percent. ${ }^{148}$ It is not possible to predict where the influence of the Criminal Justice Act and related developments will level off. If the present figures in the District of Columbia were generalized, and all other filings were fixed, the figure would reach sixty percent. ${ }^{140}$

For most circuit judges the task of reviewing criminal convictions is among the least rewarding of the tasks of their office. Only insensitive men, whom we would prefer not to employ as judges, can enjoy passing judgment on the unfortunate who are accused of crime. Also, much of the work is without challenge. While there are certainly many lively and important questions to be raised and considered about the administration of criminal justice, it is unavoidably true that there is a high chaff content which must burden the judiciary with deadening routine, and the falling reversal rate ${ }^{150}$ presages a decline in the quality and significance of the average criminal appeal. Judges devoting too much of their energies to routine cases are in danger of losing their perspective. ${ }^{151}$

Few would fail to recognize a proposal for specialized courts

${ }^{146}$ See generally Advisory Committee on the Criminal Trial, ABA Project on Mintmum Standards for Criminad Justice, Standards Relating to SPEEDy TRIAL (tent. draft I 967 ).

${ }^{147}$ Out of 3899 appeals filed, 290 were prisoner petitions and 623 were appeals from convictions. I960 ANNUAL REPORT 210, 222-23.

${ }^{148}$ Out of 7903 appeals filed, 1335 were prisoner petitions and $x 665$ were appeals from convictions. I967 ANNUAL REPORT I80, 192-95.

148 This would represent 6000 criminal appeals.

${ }^{150}$ In 1960 , about $17 \%$ of criminal appeals were successful. 1960 ANNUAL REPORT 210 . By 1967 , the rate had dropped to about 13.5\%. I967 ANNUAL REPORT I80.

151 "He who must search a haystack for a needle is likely to end up with the attitude that the needle is not worth the search." Brown v. Allen, 344 U.S. 443, 
of criminal appeals as a threat to the quality of the criminal law. Whatever may be said about specialization of courts dealing with esoteric, highly technical subjects, there is little to be said for narrowing specialization in a field so dominated by basic human values as is the criminal law. At some point, however, the rising flood of criminal cases threatens to convert the courts of appeals into semispecialized institutions.

Consequently, it seems appropriate to make some change in the handling of criminal appeals which would recognize the basic differences in their character. The primary need seems to be accelerated decision. At whatever expense may be necessary, the criminal transcript should be made available to counsel immediately after trial. Extensions of time for the submission of briefs should be allowed only in extraordinary circumstances, at least where jail sentences are involved. A special docket should be maintained for criminal appeals so that they can be assured of a hearing within four months of the trial. The judges should then give priority to reaching a decision in these cases, if necessary writing only very short opinions. By these means, the human loss resulting from the delay can be minimized and the incentives to take frivolous appeals diminished.

To balance the impact of this preferential treatment and to prevent an overwhelming predominance of criminal law in the workload of circuit judges, it may also be necessary to reduce the number of judges engaged in review. Troublesome as it is, it may be appropriate to invoke the two-judge hearing procedure on the accelerated criminal docket. If, on reading the briefs in preparation for hearing, either assigned judge deemed the case unsuited for two-judge disposition, a third judge would be assigned. If two judges heard the case and disagreed, a third would be assigned to listen to a tape of the argument and participate in the decision. In this way, the increased demand on personnel caused by the accelerated, priority docket would be offset, and the rising claim of the criminal law on the energy of circuit judges would be diminished.

Some reassurance may be gained by comparison with the procedure in the English Court of Criminal Appeals, where it is necessary to obtain leave to appeal from a conviction. ${ }^{152}$ The English method places the burden of persuasion on the appellant and imposes no duty on the one judge to give reasons when refusing to allow an appeal. There are differences in the English

537 (I953) (Jackson, J., concurring). See also Wright, The Federal Courts A Century After Appomattox, 52 A.B.A.J. 742, 747 (1966).

${ }^{152}$ See D. KARLEN, supra note 135 , at III. 
background which make it unwise to generalize too much from comparison, but it does suggest that some lesser degree of institutionalization (or some greater degree of personal involvement) can be borne at this point in the process. Nevertheless, such a change is sufficiently radical that it should not be adopted in the absence of clear need. If the panel can be filled out with an available district or visiting judge, for example, this course is preferable.

The need for control of criminal appeals will increase, however, if review of convictions is extended to review of sentences. The substantive merit of such an extension is difficult to challenge ${ }^{153}$ but its impact on our judicial institutions is worth appraising. A difficulty is the prospective increase in the amount of criminal litigation in the courts of appeals. Advocates of review have taken the sanguine view that the increase will not be great. ${ }^{15.4}$ In part, they rely on the English experience, which arises from a very different set of traditions, including a practice of screening appeals. In part, they rely on the experience in a few American state courts, where a high proportion of minor offenses are included in the mix, and where often no counsel has been provided, at least until very recent years. The data pertaining to our experience with federal criminal appeals is nonetheless disturbing. In 1967 , there were 3213 persons tried and convicted of federal crimes, and there were 1665 appeals; ${ }^{1 \ldots i}$ the resulting rate, now fifty-one percent, has been steadily growing in recent years. ${ }^{1 \text { ing }}$ If those convicted on pleas of guilty are provided with a recourse to appeal, the number of appealable convictions is increased by $23,3_{3}{ }^{157}$ If even a small percentage of these convicts exercised the right to appeal, the courts would be swamped.

A number of antidotes are under consideration. Again, there is the possibility of the specialized court for sentencing review. Such institutions exist in Connecticut, Maine, Maryland, and Massachusetts. ${ }^{158}$ A variation might provide administrative review. Either would feature the perils of a narrow specialization and an unseemly bifurcation of responsibility, since appeal of the conviction would be addressed to the regular appellate

${ }^{153}$ See generally AdvisORy COMMITTEe, supra note 146; Weigel, Appellate Revision of Sentences: To Make the Punishment Fit the Crime, 20 Stan L. Rev. 405 (r968); Comment, Appellate Review of Sentencing Procedure, 74 Yale L.J. 379 (I964).

${ }^{154}$ See Advisorx Commitree, supra note 146 , at 60.

155 Ig67 ANNUAL REPORT I92, 260.

${ }^{156}$ The comparable data for $x 960$ is 2483 convictions after trial and 623 appeals, or $25 \%$. I960 ANNUAL REPORT $210,304$.

157 I967 ANNUAL REPORT 260 (includes nolo contendere pleas).

${ }^{158}$ Advisory CommitTeE, supra note I46, Appendix A (statutes collected). 
court. Another means of controlling the flow might be to limit appellate review to relatively substantial sentences. ${ }^{159}$ This has the disadvantage of suggesting that only relatively serious crimes are worthy of appellate scrutiny.

A third approach, which may also result in appeals only by those given heavy sentences, is to deter appeals by giving the reviewing court power to increase sentences. ${ }^{160}$ This appears to discourage meritorious appeals as well as frivolous ones, and it places a heavy burden on the exercise of the right that we seek to establish. The practice was found to be unsatisfactory in England. ${ }^{101}$ Perhaps it would be less objectionable to give the United States the right to appeal, or cross-appeal, from an inadequate sentence. ${ }^{162}$ This would overcome the stated objections to a system which would relate the exercise of the right to review to the risk of an increased sentence. It would, at the same time, give the prosecution a position from which to bargain in settlement of appeals. This appears to be the major objection to such a plan, for perhaps it would give the prosecution too big a club. ${ }^{163}$ There is also a possible objection that a government appeal from a light sentence may violate the principle of double jeopardy, although this seems questionable. ${ }^{16 \pm}$

Among the alternatives, a reduction in the number of judges participating would be the least distasteful. If sentencing review does produce a very large number of filings it seems that the best means of control would be screening. Motions for summary affirmance could be delegated to a single circuit judge in appeals from sentences after guilty pleas. The luck of the draw in the selection of the single judge would play a greater role in the result than we would like to have in an ideal process, but this may be the lowest price that can be paid to provide legal restraints on the sentencing process in so large a system.

${ }^{150} I d$. at $\mathrm{r}_{3-20}$ (suggesting such a limitation for controlled experimentation with review).

${ }^{160}$ Provision for such power is made in Connecticut, Massachusetts, Maryland, and Maine. See Advisory Commitree, supra note 146, Appendix A (statutes collected).

101 Id. at 58-59.

102 This is permited in some European countries. Appellate Review of Sentences, Hearings on S. 2722 Before the Subcomm. on Improvements in Judicial Machinery of the Senate Comm. on the Judiciary, 8gth Cong., 2d Sess. 9o (statement of Professor Mueller).

${ }^{103}$ Advisory Committee, supra note 146 , at 56 .

${ }^{104}$ Cf. President's Commisston on Law Enforcement and Administration of JUStrCe, TASK Force Report: The Courts 4h-48 (x967) (advocating enlargement of the Government's right to review of adverse rulings in criminal cases). 


\section{The Law of the Circuit}

If the preceding evaluations are sound, the increase in the caseload which has exceeded the rise in dispositions per judgeship should lead to appointment of a greater number of circuit judges. This has been the response of Congress to congestion in the past ${ }^{105}$ and was urged by the Judicial Conference in 1964 and $1967,{ }^{160}$ but concern among the judges over the wisdom of this approach is reflected by pressure's being directed instead to increase the rate of dispositions per judgeship and to inhibit the flow of appeals. ${ }^{167}$ Increasing the number of circuit judges is not likely to reduce the prestige of the position to such an extent that qualified members of the bar would be reluctant to accept appointments. Nor is it likely that a diminution in the quality of candidates would result. ${ }^{168}$ Concern over additional judgeships has deeper roots: as more judges are added to a circuit, the likelihood of intracircuit disagreements increases because of the greater chance that an aberrational minority may gain control of a panel.

\section{A. En Banc Procedure and the Size of the Circuit}

The "law of the circuit" has emerged as a response to the Supreme Court's incapacity to resolve intracircuit conflicts. It is derived from precedent; every decision of a panel of a court of appeals is accorded special respect by all the judges of the circuit, thus extracting a measure of deference to precedent perhaps somewhat in excess of that ordinarily shown other circuit opinions. ${ }^{169}$ Inevitably, however, there are instances when the

${ }^{165}$ During their first decade, the ten courts of appeals were staffed with a total of 30 judgeships. With increased responsibility and stature and the growth of the nation, there was a gradual increase in the caseload; to meet such increases, additional judgeships were created. In I929, the staff of the Eighth Circuit, which had served an immense area, became large enough to support a split; the Tenth Circuit was created at that time. Act of Feb. 28, 1929, ch. $363, \S 1,45$ Stat. 1346. By 1968, there were 98 circuit judgeships assigned to the eleven circuits. 28 U.S.C. $\$ 44$ ( 1964$)$. See generally Staff of Senate Comm. on thF. Judiciary, 85Th Cong., 2D Sess., Legislative History of the United States Circuit Courts of Appeals and the Judges Who Served During the Period I8or Through March i958 (Comm. Print 1958).

${ }^{166}$ ig64 Report of the Proceedings of the Judictal Conference of the UNITEd STATES $63 ; 1967$ id. 9.

${ }^{167}$ For a statement of judicial opposition to the appointment of more judges see Letter from Judge Albert Bryan to Will Shafroth, Jan. 19, I967, in Shafroth, supra note 33, at 3I4-I5. See also Gibson, Some Observations on Our United States Courts of Appeals, 35 U. Mo. KaN. Ciry L. REv. 26r, 270 (I967).

${ }^{168}$ For a description of the present mode of selection of judges and the rolc played by the American Bar Association see J. Grossman, Lawyers and Judges $\left(x_{5} \sigma_{5}\right)$.

169 The stricture thus imposed is not much different from that imposed on federal judges in deciding issues of state law arising in diversity cases; it is con- 
law of the circuit fails to take shape in the ordinary course of panel decisions. ${ }^{170}$ The device now usually employed in this situation is the en banc proceeding. In form, such a proceeding enables the judges of a circuit to settle their differences, and the threat of an en banc rehearing restrains separate panels from indulging unique values of their own to reach judgments in which the majority of their colleagues would not concur.

The en banc procedure is a relatively recent innovation. The original circuit courts of appeals were each composed of three judges who sat together. As additional judgeships were created, the practice evolved of sitting in panels of three; the idea was apparently borrowed from the English Judicature Act. ${ }^{171}$ Since the controlling provisions of the Judicial Code prescribed threejudge courts, it was assumed that a larger assembly of circuit judges was not authorized to decide cases. Indeed, the Ninth Circuit so held in 1938 in Lang's Estate v. Commissioner. ${ }^{172}$ Apparently, it was contemplated that a division of opinion among the judges of an intermediate court would lead to certification of the troublesome issue to the Supreme Court. ${ }^{173}$ In Lang's Estate, the Ninth Circuit followed this procedure, and the Supreme Court answered the certified question without commenting on the propriety of en banc proceedings. ${ }^{17 \pm}$ Soon thereafter, however, the Court, in approving a decision of the Third Circuit en banc, $^{175}$ disclaimed responsibility for resolving intracircuit con-

siderably less restrictive than the restraint imposed by the doctrine of the law of the case, when a case is brought before two different panels of the same court on successive appeals. See Lincoln Nat'I Life Ins. Co. v. Roosth, 306 F.2d IIo, Ix3 (5th Cir. 1962), cert. denied, 372 U.S. 912 ( 1963 ).

${ }^{170}$ This situation is illustrated by the Fifth Circuit cases dealing with the liability of the United States under the Tort Claims Act for negligence in air-sea rescue operations. This would seem to be a relatively neutral issue on which agreement would not be so difficult to obtain. Successive panels of that court have, however, been unable to accept the plain implications of the decisions of earlier panels, and it can be inferred that the outcome of such a case in that court is dependent on the luck of the draw in the selection of the deciding panel. Compare United States v. Lawter, 219 F.2d 559 (5th Cir. I955), with United States v. Gavagan, 280 F.2d 319 (5th Cir. I960), and United States v. DeVane, 306 F.2d 182 (5th Cir. 1962).

${ }^{171}$ D. KARLEN, supra note 135 , at 140 . For a description of the state court precedents see Alexander, En Banc Hearings in the Federal Courts of Appeals: Accommodating Institutional Responsibilities (Part I), 40 N.Y.U.L. REv. 563, 565-67 ( 1965 ).

${ }^{172} 99$ F.2d $867,869-70$ (9th Cir. 1938).

173 See 2 I CONG. REC. I0,222 (I890) (statement of Senator Evarts). This was the technique employed when a conflict arose within the old circuit courts and remains possible today. 28 U.S.C. \& I254(3) (I964). See, e.g., United States v. Barnett, 376 U.S. 68I (1964).

${ }^{174}$ Lang v. Commissioner, 304 U.S. 264 (1938).

${ }^{175}$ Commissioner v. Textile Mills Sec. Corp., II7 F.2d 62 (3d Cir. I940). 
flicts and imposed on the courts of appeals the responsibility for maintaining stable law within their circuits. ${ }^{170}$ The Judicial Code was revised in 1948 to make explicit provision for en banc procedure. ${ }^{177}$ In 1953, the Supreme Court went a step further, requiring that each court of appeals formulate procedures for sitting en banc and for permitting litigants to request en banc rehearings. ${ }^{178}$ The Court has not yet, however, prescribed any standards for selecting cases for en banc treatment, and circuits vary widely in the use they make of the procedure. In some circuits, en banc rehearing is only a remote possibility; until recently the Sixth Circuit had decided only two cases en banc. ${ }^{170}$ In other circuits, rehearing is granted relatively often. ${ }^{180}$

The en banc procedure is, of course, time-consuming for the judiciary and burdensome to litigants. Even in a circuit of moderate size, its demands impair the rate of dispositions per judge. If the court takes an earnest view of its obligations, all panel opinions must be circulated before publication to give disapproving members of the court an opportunity to persuade their colleagues to convince the deciding panel to moderate its decision or to grant an en banc rehearing. Motions for hearing or rehearing en banc should be considered by all the judges of the circuit. The oral argument is difficult to schedule because it falls outside the usual pattern; the conference of the judges is time-consuming; and an en banc opinion must be widely circulated before it is handed down. Also, there is an inescapable delay caused by the process of screening en banc cases. Even where the panel originally assigned promptly identifies a case as suitable for en banc procedure, the time lag between oral argument and disposition is generally twice that of a panel disposition. If, as more often happens, the en banc decision is not made until after panel consideration, the time lag may be four times as great. ${ }^{181}$ Thus, a litigant caught in an intracircuit conflict may have to wait an additional six or eight months to obtain satisfaction. ${ }^{182}$ When a

${ }^{176}$ Textile Mills Sec. Corp. v. Commissioner, 314 U.S. 326, 333-35 (1941).

17728 U.S.C. $\$ 46$ (c) (1964).

${ }^{178}$ Western Pac. R.R. Corp. v. Western Pac. R.R., 345 U.S. 247, 250-62, 267-68 (I953). An example of the exercise of this responsibility is Rule 25(a) of the Fifth Circuit.

${ }^{179}$ I967 ANNuAL Report rog; Alexander, En Banc Hearings in the Federal Courts of Appeals: Accommodating Institutional Responsibilities (Part II), 40 N.Y.U.L. REv. 726, 755 ( 1965 ).

${ }^{180}$ The Fourth Circuit held $3 x$ en banc hearings in the fiscal year $1966-67$. This was more than a third of the $1966-67$ total for all circuits. I967 ANNUAL REPORI IO9.

181 The figures are based on a study of the Second and Third Circuits, in Alexander, supra note $17 \mathrm{I}$, at 577 . It should be pointed out that some comparable delay is a feature of any rehearing procedure.

182 The prospect of an en banc rehearing on the motion of one of the judges 
judge initiates the procedure, there is a breach of the adversary tradition. ${ }^{183}$ Unwillingly, a litigant may be subjected to unexpected and extraordinary toils, and personal relationships on the bench are likely to be strained by what some may view as a gratuitous intermeddling of colleagues in the decisions of their peers. ${ }^{18 t}$ Yet judges need the power to request the procedure, for the responsibility for maintaining the law of the circuit is theirs, not the litigants'.

The benefits from the use of en banc procedure are somewhat more limited in practice than might be expected. En banc hearings have sometimes resulted in evenly divided courts, ${ }^{185}$ which not only failed to resolve a conflict, but probably exacerbated it by finding it unresolvable. In cases where certiorari is ultimately granted, the en banc proceedings serve little more than to delay a case, although they do give the Supreme Court the benefit of another decision. ${ }^{180}$ Finally, there may well be instances in which dissenting judges have returned to three-judge panels in later, similar cases and proceeded to distinguish the en banc precedent on grounds that would not have persuaded the judges who voted to establish it. ${ }^{187}$ The only remedy for such deviation would be another en banc proceeding.

Despite these shortcomings, en banc procedure is essential

on the panel adds a dimension of uncertainty to panel decisions. For an extreme case in which rehearing was granted almost a year after the initial decision was announced see Yanow v. Weyerhaeuser S.S. Co., 274 F.2d 274 (gth Cir. x959), cert. denied, 362 U.S. 9I9 (I960).

${ }^{183}$ Perhaps more offensive to the traditional practice of control of litigation by the parties is the informal en banc procedure which the Second Circuit employed in United States v. Freeman, 357 F.2d 606 (2d Cir. I966). A footnote was appended to the panel decision announcing that the other judges of the court having no responsibility for the decision had been consulted and had approved the opinion of the court.

${ }^{184}$ See Note, The Second Circuit: Federal Judicial Administration in Microcosm, 63 CoLUM. L. REv. 874, goo-08 ( 1963 ). But cf. Maris, Hearing and Rehearing Cases in Banc, 14 F.R.D. 9r (1954).

${ }^{185}$ I962 ANNUAL REPORT 9. Alexander found I4 instances of deadlock in a sample of 84 en banc courts with an even number of judges sitting. Alexander, supra note I7I, at 584 .

${ }^{180}$ Alexander found that the Supreme Court gives review in one out of three cases that had been heard en banc and were pursued to the Court. Alexander, supra note 179 , at $746-58$.

${ }^{187}$ For a discussion of presence of voting blocks on courts of appeals and prediction of decisions according to the composition of a panel see Goldman, supra note 88. Brief reference to such instability in the Court of Appeals for the District of Columbia with regard to criminal matters is made by Attorney General Katzenbach in his letter to Judge Bazelon, quoted in Kamisar, Has the Court Left the Attorney General Behind? - The Bazelon-Katzenbach Letters on Poverty, Equality and the Administration of Criminal Justice, $54 \mathrm{KY}$. L.J. 464, 491-94 (1966). See generally The United States Court of Appeals for the District of Columbia: 1965-1966 Term, 55 GEo. L.J. I (I966). 
to a healthy law of the circuit, given the present operation and structure of the courts of appeals. As long as the three-judge panel making decisions is not too small a segment of the whole court, this means of keeping the panels in step with one another is probably effective enough to make its inefficiencies worth bearing. As the court is enlarged to meet the burgeoning caseload, however, there is a serious threat that the enterprise of maintaining the law of the circuit will gradually collapse because of the inherent weakness of its operation. At some point, en banc procedure becomes entirely unmanageable. Twenty judges cannot conduct a meaningful hearing, nor can they effectively deliberate. As the number of judges within a circuit is increased, en banc procedure becomes not only less effective, but more costly and more dilatory and therefore less likely to be invoked. Thus it becomes less useful as an implicit restraint on the individual panels. Indeed, as the size of the court is increased, the likelihood of differences among the judges is increased, and a wider variety of idiosyncrasies is likely to appear in their decisions. ${ }^{188}$ While there is a limit to the number of different viewpoints possible in a given case, nevertheless, the larger the number of panel variations possible, the more likely it is that an aberrational view can command an occasional majority. The finding of a committee of the Judicial Conference that a court of more than nine judgeships is likely to be more unstable than a healthy legal system should tolerate seems reasonable. ${ }^{189}$ It might even be that the point of disutility is below nine, for in a court of nine only a third of the circuit's judges are responsible for the fidelity of a decision to the law of the circuit. It seems fair to conclude that the considerations which prompted the invention of the law of the circuit and en banc procedure are threatened by continued enlargement of the number of judges participating in the work of one court.

${ }^{188}$ As judges are added, theoretically the increase in the number of sources of conflict is much greater than arithmetic. Thus, the addition of a tenth judge increases the number of possible variations in the composition of three-judge panels from 84 to 120 . There are 220 variations possible in a twelve-judge court, and 455 in a fifteen-judge court.

${ }^{189}$ A difficult question is posed as to the maximum effective size of a court, sitting in divisions or panels, which is expected to operate as a unit of administration. A committee of the Judicial Conference of the United States has stated simply that no circuit can be expected to maintain "its efficiency and unity as an institution" if the membership of its court of appeals exceeds nine active judges. 1964 ANNUAL RePORT 15. The committee did not enlarge on its reasons, and its recommendations were overridden when the Fifth Circuit was enlarged temporarily to a strength of thirteen judgeships. Its rule of nine was apparently dispatched for all time in 1967 when the Judicial Conference recommended the enlargement of the Ninth Circuit to thirteen judgeships and the permanent enlargement of the Fifth Circuit to fifteen. ig67 Report of the Proceedings of the Judicial Conference of the United States 9. 
Determining the maximum size of a circuit, however, is not an easy matter. While the rather brief operation of the Fifth Circuit as a fifteen-judge court may provide some evidence, ${ }^{190}$ it is difficult to gain any insights about the effect of a large number of judges on intracircuit stability from a case-by-case analysis of its performance. There are simply too many special factors at work in the Fifth Circuit. ${ }^{191}$ Even such an analysis of the thirteen-judge Ninth Circuit would provide little guidance, for too many variables are at work in any particular panel decision. ${ }^{192}$

\section{B. Preserving En Banc Procedure:}

Supernumerary Judges and Realignment of Circuits

The courts of appeals could be enlarged and en banc procedures preserved if judges were added who were not expected to sit en banc. Such additions could be made in several ways. A staff of judges could be appointed to the Federal Judicial Center for assignment wherever their services were most needed. ${ }^{103}$ Alternatively, extra judges might be assigned to the Court of Claims or the Court of Customs and Patent Appeals. ${ }^{104}$ Another possibility would be to increase the availability of district judge manpower. District courts in the congested circuits could be overstaffed, and the judges assigned to such districts could serve on a rotating basis on the appellate bench. Though these additional judges might contribute to doctrinal instability either because of their unfamiliarity with the law of the circuit or their personal idiosyncrasies, this danger could be minimized by assigning them cases in areas, such as diversity litigation, where maintaining the law of the circuit is least troublesome or important. This approach, at least as a temporary solution, seems to have considerable merit.

100 Alexander, supra note 179 , at 726,745 .

101 See note I97 infra.

102 Karl Llewellyn thought that such a case-by-case inquiry was feasible. See K. Lleweliyn, The Common Law Tradition: Deciding Appeals (ig60). But exploring the question whether a system is operating well or ill on the basis of a panel's performance in a particular case frequently elicits a judgment which tells little more than the evaluator's predilections.

103 See generally pp. 563-66 supra.

104 This has been suggested as a means of improving the status of the Court of Customs and Patent Appeals. See ABA Section of Patent, Trademark and Copyright Law Recommendation Presented to the ABA Board of Governors, May 15, 1967, on file at the Harvard Law Review; p. 610 infra. The Court of Claims is probably already overstaffed. It was enlarged to seven judges by Act of May II, x966, Pub. L. No. 89-425, 80 Stat. 139. These judges could as well sit in panels of three, thus freeing manpower for use in the courts of appeals. There is precedent for this proposal in the use made of the Commerce Court judges after their court was abolished. See Staff of Senate Comm. on the Judiciarx, supra note 165 , at 20. See also p. 601 \& note $28 \mathrm{I}$ infra. 
The present circuit boundaries are old and irrational, ${ }^{105}$ and another frequently discussed solution for the problems of congestion and instability has been a realignment of the circuits. Halving both the Fifth and Ninth Circuits, the largest in both geographical size and number of judgeships, would immediately relieve the problem of stabilizing the law of the circuit in those two regions. Thus, when reporting on the problems facing the Fifth Circuit, a committee of the Judicial Conference proposed to divide its jurisdiction into halves, thereby creating an additional circuit. ${ }^{196}$ Splitting the Fifth Circuit would avoid the need to appoint more than nine judges to a single circuit to meet congestion and reduce the present inconvenience to litigants caused by its large geographical size. ${ }^{107}$

There are, however, several substantial objections to circuitsplitting. First, an increase in the number of circuits would produce additional intercircuit conflicts, and the Supreme Court already is too overburdened to handle these at their present level. ${ }^{108}$ The likelihood of intercircuit conflict would be further increased by the parochialism attendant on the split. ${ }^{100}$ The more states included within a single circuit, the broader the experience judges will bring to the court, not simply because of the slight differences

\footnotetext{
${ }^{195}$ The boundaries are prescribed in 28 U.S.C. $\$ 4 \mathrm{I}$ (1964). See map, p. 588 infra.

${ }^{197}$ When the Evarts Act was debated in 1890 one senator proposed an elevencircuit plan, dividing the southern states along lines similar to those proposed by the recent Judicial Conference committee. 21 Cong. Rec. Io,219 (1890) (proposed amendment of Senator Ingalls). Like the committee, he thought Alabama, Florida, Georgia, and Mississippi should compose one circuit, and he proposed to join Texas and Louisiana with Arkansas for the other. The senator also objected to the size of the proposed Eighth Circuit, and his position was adopted in 1929 when the Tenth Circuit was carved out of the Eighth. Act of Feb. 28, 1929, ch. 363, 45 Stat. 1346 .

Despite its merit, the committee proposal was seriously defective in focusing so squarely on the Fifth Circuit, a court very actively engaged in civil rights litigation. It has achieved notice in recent years for its vigorous enforcement of the national law. E.g., Note, Judicial Performance in the Fifth Circuit, 73 Yate L.J. 90 ( 1963 ). This record has been made sometimes over the hostility of district judges, see, e.g., United States v. Cox, 342 F.2d 167 (5th Cir. 1965), sometimes over inflammatory dissents, see, e.g., Armstrong v. Board of Educ., 323 F.2d 333, 352-6I (5th Cir. I963) (Cameron, J., dissenting), and, on occasion, in conflict with governors, see, e.g., United States v. Barnett, 346 F.2d 99 (5th Cir. 1965). Some were quick to find in the committee's proposal a threat to the civil rights movement. Whether these fears were realistic or not, they made the plan undesirable by their implication that legislative revision of judicial institutions would be done to affect decisions. See Wright, suspra note 75 , at 955 . The committee would have been strategically wiser to advance the plan at a different time or broaden it to include more circuits.

${ }^{198}$ See p. 553 supra.

${ }^{109}$ Wright, supra note 75, at 974-76. See also pp. 602-03 infra.
} 
in values we might expect to find between Californians and Oregonians, but because a wider range of political interests will participate in selecting the judges for the multi-state circuit. A one-state circuit, for example, is in danger of becoming the patronage preserve of a single senator. ${ }^{200}$ Finally, the geographical boundaries of a circuit may affect a judge's view of his responsibilities. A judge whose jurisdiction is locally confined is in danger of thinking of himself as having local obligations. But the courts of appeals are national courts and should not maintain a quasiregionalism..$^{201}$ It is true, however, that the Ninth Circuit could be divided without creating a circuit of less than four states.

Even if these reasons may not entirely foreclose considering a split of the Fifth and Ninth Circuits, the urban character of the other busy circuits creates more serious problems. Both the Second Circuit and the District of Columbia Circuit now have nine judges working at full capacity, but dividing either of these circuits is impractical. With well over half of the business of the Second Circuit coming from the Southern District of New York, an equal division of the circuit would require splitting the island of Manhattan. The two tables which follow are intended to give the reader the materials with which to try his hand at circuit realignment. ${ }^{202}$ An extended effort at the task has persuaded the author that any net gain in stability from the above plans is too trivial to make realignment an attractive pursuit. And even the simple splitting of Fifth and Ninth Circuits is not justified in light of the other and better alternative, discussed below.

\section{Substantive Division of the Circuits}

A better solution than creating smaller geographical units is to divide the large circuits into divisions based on subject matter of cases. ${ }^{203}$ For purposes of illustration, let us assume a court with rooo filings and twelve judges. Such a court would be expected

${ }^{200}$ See generally J. Harris, The Advice and Consent of the Senate 302-24 (1953); J. Grossman, supra note 168 , at $156-95$.

${ }^{201}$ See Wisdom, The Friction-making, Exacerbating Political Role of Federal Couris, 2 I Sw. L.J. 4II (Ig67). But cf. Armstrong v. Board of Educ., 323 F.2d 333, 352-6I (5th Cir. 1963) (Cameron, J., dissenting); United States v. Wood, 295 F.2d 772, 785-89 (5th Cir. I961) (Cameron, J., dissenting).

202 The data in the map is derived from ANNUAL REPorts. The averages include appeals from the district courts plus a factor representing a proportionate share of the administrative appeals and original proceedings, so that the numbers should approximate the number of appeals which would be filed in an appellate court serving only the one district. Map reprinted with permission from volume 393 of the Federal Reporter, Second. Copyright 1968 by the West Publishing Company, St. Paul, Minnesota. All rights reserved.

${ }^{203}$ For a discussion of the use of divisions in state appellate courts see AMERICAN Judicature Society, Solutions for Appellate Court Congestron and Delay 3-6 (1963) (Information Sheet No. 24). 


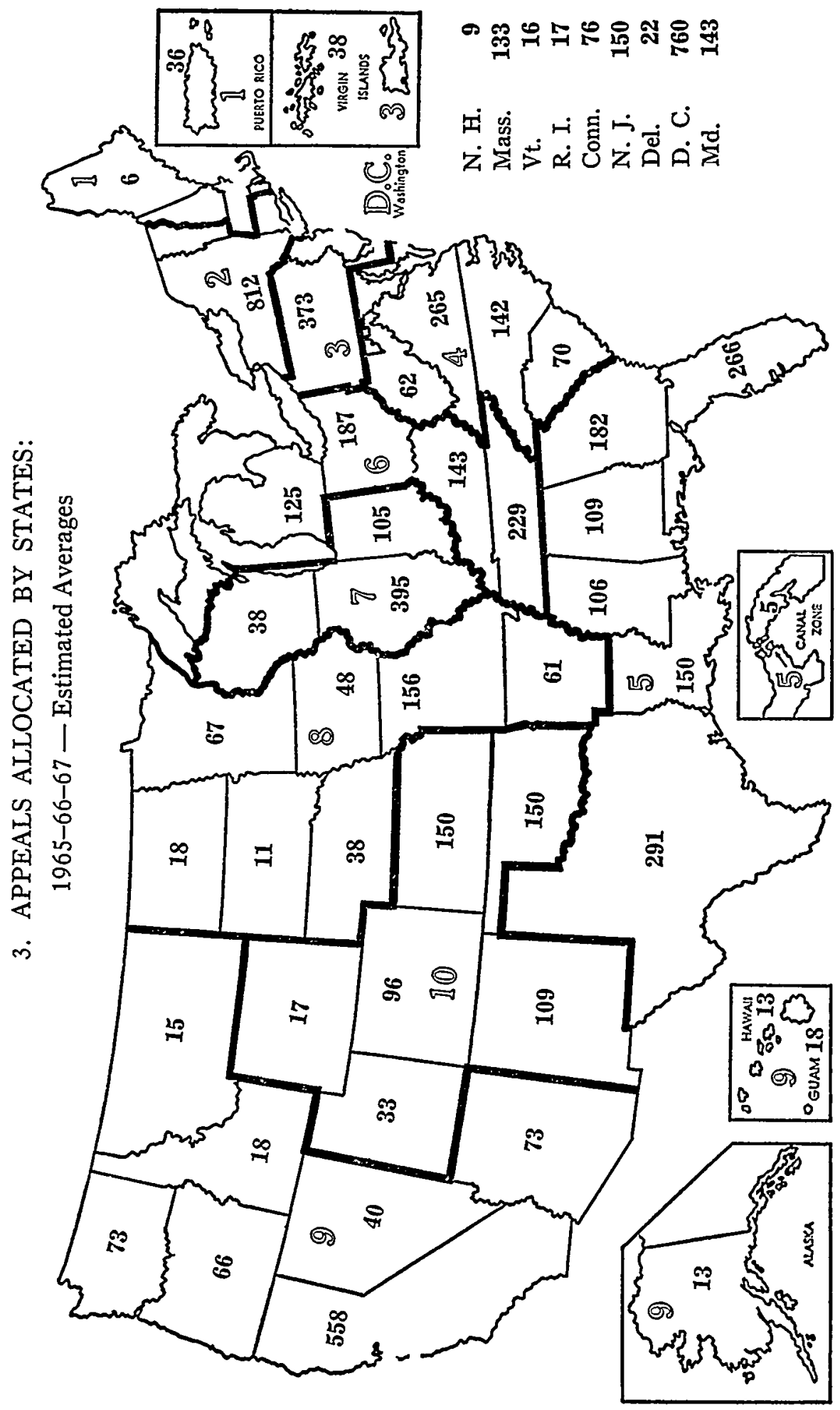




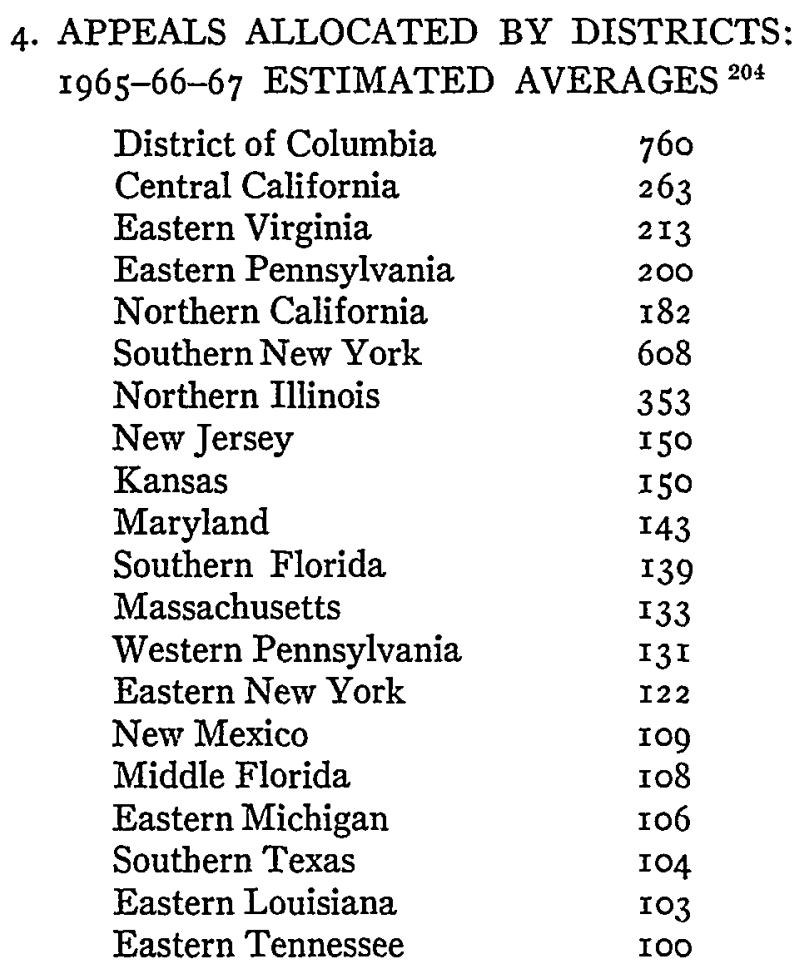

to hear and decide in excess of 600 cases a year, the balance being terminated before hearing or submission. ${ }^{20.5}$ On the basis of records available for prior years, it would be a simple task to divide the circuit's docket into equal halves by subject, so that about 500 filings will be listed on the docket of each division. For example, the 500 cases for Division A could be composed of the following categories, estimated with reasonable accuracy: about I 50 administrative appeals, thirty tax appeals, twenty labor relations cases, eighty diversity and local cases, I30 habeas corpus petitions from state prisoners, seventy government property and contract claims, and perhaps twenty government tort claims. ${ }^{200}$ Division B would hear the balance. Only those judges assigned to each division would participate in the formulation of the law of the circuit with respect to the matters assigned to its docket;

\footnotetext{
${ }^{204}$ The figures for the two California districts are based on I967 data only, because California was split into four districts in 1966. Act of Mar. 18, I966, Pub. L. No. 89-372, 80 Stat. 75 .

${ }^{205}$ About two appeals in five do not reach hearing. In 1967,2225 cases were disposed of without hearing or submission; 4468 were decided by the courts of appeals. I967 ANNUAL REPORT I80.

${ }^{200}$ These figures are roughly proportional to recent experience in the Ninth Circuit. See, e.g., I967 ANNuAd REPORT 192-95 (comparable data on all circuits).
} 
in this way, the number of participants could be kept within manageable limits, assuring a reasonable measure of stability. It would be expected that all the judges assigned to a division would maintain an awareness of the work of their colleagues within the division, and that the group would sit en banc to resolve vexing problems. The law applied by the judges assigned to the other divicion, however, would not be their responsibility or concern.

On the basis of 500 filings per division, six judges would be assigned to sit on cases assigned to Division $\mathrm{A}$; the remaining six, to Division $B$. Judges might be rotated between the divisions, assuring a full range of experience for each judge while limiting in each substantive area the number participating in a particular year in the making of the law of the circuit. Every term, two judges from each division would exchange assignments, so that no judge would remain in the same division for more than three years.

A strength of this system would be its flexibility. In addition to the rotation of judges, no litigant would be regarded as having a right to have his case decided by a panel from one division rather than the other. However, the lines between divisions would not be "jurisdictional," and in urgent situations, matters might be assigned to any panel available, irrespective of divisional arrangement. If one division proves to be overburdened, divisional lines could be rearranged or personnel assignments could be altered from an even distribution of judges to a seven-to-five division. When visiting judges, senior judges, or district judges are used to fill out the court, they could be allocated between the divisions according to immediate need.

Moreover, under this mode of operation a circuit could easily assimilate more permanent judges. If the Fifth Circuit is to have fifteen judges, its docket might have three divisions, each employing the services of five judges. On the addition of the twentysecond judgeship, a fourth division would be added. With five divisions, a single circuit could assimilate as many as thirty-five judgeships and yet maintain a reasonably stable law of the circuit. At some point, of course, the subject matter of the docket could not stand further subdivision, and so there is an absolute limit to the number of divisions that might be created. Perhaps the number of judges assigned to a division could exceed seven, but at some point, not much beyond that number, it seems likely that the increased stability gained by the division scheme would diminish below the point of justification for the change.

The most obvious critical response to this proposal is to condemn it as a specialization of the federal judiciary. ${ }^{20 \pi}$ But under

${ }^{207}$ See Rifkind, A Special Court for Patent Litigation? The Danger of a 
this plan there is limited danger of specialization, for the efforts of judges would be focused for limited periods of time and on a wide range of cases. The breadth of subjects assigned to each docket and the steady turnover of personnel greatly reduce the likelihood that judges would become so specialized and absorbed in the intricacies of their expertise as to be unable to view problems as a whole. Indeed, the plan may have the advantage of diminishing the impact of "expertism" on federal law. The present general docket affords the judge who formerly was an experienced tax or utilities lawyer an opportunity to overpower his less expert colleagues. Under the proposed plan, as judges concentrate on a narrower range of subjects, the disparity in the level of expertise should be reduced. Also, the proposed dockets would be wide enough in range to foreclose any danger of the harm attendant upon intellectual inactivity, and triennial rotation would prevent the judges from settling too deeply into intellectual ruts.

The effect of specialization on the recruitment of judges is a related concern, and the fear has been expressed that the best lawyers would be less willing to devote their careers to an office too restricted in compass. It seems quite unlikely, however, that the kind of change proposed would make the office less attractive to the best lawyers, for it would surely be recognized that the effect of the change would be to enlarge the creative opportunities of the circuit judges, as well as to relieve some of the burdens of the present arrangement. Circuit judgeships would surely remain among the most prestigious professional opportunities available to American lawyers. Another danger of specialization is that it indirectly affects the integrity of the process of judicial selection. When a court is limited to a few kinds of matters, those involved in the litigation are quite likely to make an extraordinary effort to control the selection of its judges. This was, for example, the undoing of the old Commerce Court, which failed because it became a railroaders' court. ${ }^{208}$ But sharply identified interests tend to neutralize themselves in appointments to courts of general jurisdiction. For this purpose, it is clear that the rotating assignments in the proposed plan would evoke generalized, not specialized, appointments, and there would be no greater chance than at present for any interest to dominate the selection of circuit judges.

Other objections to the proposal are more substantial. Undeniably, by dividing the court the plan would create some risk of aberrational decisions by a minority of a circuit, for the judges

Specialized Judiciary, 37 A.B.A.J. 425 (I95I) ; Miller, Can Tax Appeals Be Centralized?, 23 TAXEs 303, 306 (1945).

${ }^{208}$ See F. Frankfurter \& J. LaNdis, supra note 7, at 162-74; Rightmire, 
assigned to a particular division might not be representative of the whole. ${ }^{209}$ But this risk is not different in kind from the danger involved in permitting any small group of judges to make decisions for the whole. Moreover, the proposed scheme has enough flexibility to handle this problem. The dockets and personnel assignments would be subject to annual review by the judges of the circuits sitting in the Circuit Council. ${ }^{210}$ Thus there is available a measure of indirect control by the group, which would be lost if the circuits were divided geographically. The Circuit Council might be tempted to let a judge's decisions influence reassignments, an undesirable practice but one which may not be totally absent in the present method of assigning cases to panels. To some extent, careful administration of the divisions could reduce a tendency in the scheme toward schisms and cliques. For example, to avoid the permanent pairing of judges in the rotation, new judges could be put at the bottom of the rotation order in the divisions to which they are assigned. The tendency of a rhythm of rotation to keep some judges together can also be restrained by increasing the number of divisions, so that the judges are not full-time members of one subgroup, but are members of more than one division. Carried too far, this would make the scheme too complex. But it would not, for example, be difficult to divide a docket four ways rather than two, assigning each judge to half-time duty in two of the four divisions.

Another concern is the prospect that the scheme might purchase geographic stability at the cost of doctrinal instability over time from the rapid turnover within the divisions. But the risk of instability over time should be weighed against the stabilizing influence which results from defining the judicial office in terms of specific substantive responsibilities. This proposed substantive division would lead judges to define their duties as the making of tax and labor law rather than regional law, rendering the responsibility for doctrinal stability explicit. This self-image might usefully be contrasted with the definition of office that would result from the splitting of circuits geographically, which might lead judges to think of their creative duties as law making for Manhattan or some larger area. Also, instability attendant on quick turn-

Special Federal Courts, I3 ILL. L. REv. 15, 97 (19r8).

${ }^{209}$ For example, the recent school segregation cases in the Fifth Circuit, United States v. Jefferson County Bd. of Educ., 372 F.2d 836 (5th Cir. I966), cert. dentied, 389 U.S. 840 ( 1967 ), were decided by a nine-to-three vote. Per curiam opinions on rehearing en banc are reported in 380 F.2d 385 ( 5 th Cir. 1967 ). If the court had been divided into three divisions, it is theoretically possible that the minority group would have been able to decide the case.

210 For the operation of the Councils see 28 U.S.C. $\$ 332$ ( 1964$)$. They were created by Act of Aug. 7, 1939, ch. 50r, § I, 53 Stat. 1223. 
over must be balanced against the risk of intellectual torpor in extending greatly the length of their service within a single division. The assignment of each judge to two divisions with a biennial revision of one half of the judge's duties might reduce the risk enough to permit the use of a four-year norm. Alternatively, if greater weight is to be placed on the need for stability over time, judges could be kept on partial call for a period following their rotation. Thus, the rooo-case docket might be divided into three divisions. Seven judges would be assigned to each, one rotating each year, but only the four junior in service in each division would sit on ordinary panels, the other three being available only as ballast in the operation of the divisional en banc procedure. Each judge would devote most of his time to one division during his three- or four-year assignment, while retaining for two or three years some control over radical shifts of view resulting from his departure. Within the framework of a twelvejudge court, both of these suggestions could easily be used. Six divisions would be created, with each judge sitting regularly on two of the six, and on en banc proceedings only in one or two of the others. This method of operation would tend to preclude clique formation, and, by extending the divisional turnover period to six years, would assure reasonable stability over time to the law of the circuit.

These added wrinkles, however, would cause problems in the larger circuits, the Fifth, Ninth, and Tenth. The proliferation of divisions would give rise to some difficulty in scheduling court dates convenient to all parts of the circuit. If, for example, each division must be available in Jacksonville and Fort Worth every month, the amount of travel required of the judges would be unreasonable. A partial answer to this problem could be found in the use of somewhat less complex schemes in the far-flung circuits. Alternatively, a remedy might lie in a partial circuit split, a reasonable possibility with a divisional scheme. Some divisions, handling classes of cases with respect to which the harmonization of national law presents less of a problem, might be localized without harm to the policies served by maintaining the unity of the larger circuits. Thus, little would be lost if the divisional scheme were employed to divide the geographically large circuits with respect to diversity and criminal litigation. ${ }^{211}$ For example, it might be contemplated that in the Fifth Circuit some

211 The homogeneity of the national law is, of course, a serious problem for criminal litigation, but this is an area where the Supreme Court can be expected to handle the problem of intercircuit conflict. Furthermore, the percentage of routine cases presenting no significant legal issues is very high, and the need for dispatch in the handling of these matters is great. 
judges would be permanently assigned to a division which would hear all diversity and criminal matters coming up from Texas, Louisiana, and Mississippi. Or, perhaps, there might be three such geographical divisions. All the judges would then be available to devote about half their time in rotation among the other substantive divisions. The subject-matter divisions might thus be limited in number to two or three so that they could sit frequently enough to provide adequate service to all parts of the circuit. This approach to the problem of the big circuit would appear to secure most of the benefits of the geographic split, without aggravating the problem of intercircuit instability.

Another hazard is that the administrator of this plan might be unable to keep case assignments discrete by divisions because of overlapping of issues in individual cases. The administrative task of assigning cases, however, is easier than might appear, for many, if not most, classes of federal litigation are integral and not overlapping. ${ }^{212}$ Thus, in the simple two-division breakdown, it is easy enough to select categories, such as revenue or administrative appeals, which present no problem of identification. And a miscellaneous docket would be maintained for those cases containing issues beyond any one division's docket. A possible division of the Fifth Circuit docket reveals little likelihood of overlap if the proposed scheme were employed. After the diversity and criminal cases are set aside for separate treatment, 500 federal civil appeals in the circuit could reasonably be anticipated for the current year. They might be divided thus:

Division A: Employers Liability (25); Original Proceedings (20); Taxation (85); U.S. Tort Claims (30).

Division B: Bankruptcy (30); Eminent Domain (10); Labor Relations (80); Labor Standards (15); Miscellany (35).

Division C: Administrative Business Regulation (25); Antitrust (10); Civil Rights (70); Government Contracts and Property (20); Miller Act (10); Patent \& Trademark (15); Social Security (20).

These categories are not all integral. It is possible, for example, that a tort claim against the Government might be joined with a claim that property is being taken without just compensation. More troublesome, perhaps, are the situations in which issues might be presented out of the usual context, as where the Government asserts a tax claim in a bankruptcy proceeding. Such

${ }^{212}$ But cf. The Supreme Court, 1967 Term, 82 HARv. L. REv. 63, $3^{1} 3$ \& n.10 (1968). 
complexities would require a careful exercise of the administrator's discretion in assigning cases to divisions. But difficulties should be rare, and the worst consequence of an incorrect or incomplete assignment would be that a case might be decided by a different group of judges than the parties might have expected. But the likelihood that an "outside" panel would depart from the law of the circuit because of inexperience with the substantive field of law would be tempered by their awareness that they are in an unusual situation. The ability of federal judges must not be slighted; they certainly should have no more difficulty understanding precedents from another division than would any other participant in the litigation.

Interdivisional splits on interpretations of Rules of Civil Procedure, provisions of the Administrative Procedure Act, or the Judicial Code, which govern matters coming before all divisions, will not be uncommon. However, this is not a serious problem for the reason that such provisions pertaining to procedure and institutional arrangements are not, despite their apparent generality, applicable with precisely equal force to all classes of cases, without regard for substantive differences. That discovery rules, for example, operate somewhat differently in antitrust cases and civil rights cases should not be regarded as extraordinary or disturbing; while the institutional apparatus is the same, the mix of values weighed in the decisions is inevitably different. There is no unfair discrimination in treating different cases as if they were different; nor is there disturbance to legal planning activities, because institutional practices are too remote from their concern. $^{213}$

Still, the presumption in favor of uniformity in the Federal Rules must be acknowledged, and the division scheme cannot fully meet its demands. Since a problem of procedure will often be raised in a case posing a substantive issue as well, procedural cases must be handled with somewhat less concern for unifying discipline. It seems sufficient to designate one of the divisions as having a senior responsibility for matters pertaining to the rules of procedure and the interpretation of the Judicial Code, and its decisions would generally establish the law of the circuit with respect to these questions. Other divisions would be expected to conform, unless there appeared to be a compelling substantive reason for proceeding differently. It would seem appropriate in circuits having a single division charged with responsibility for diversity of citizenship cases that such a division be designated as the procedure division as well, both because a high percentage of

${ }^{213}$ Cf. H.M. Hart, The Relations Between State and Federal Law, 54 Conum. L. REv. 489,513 (1954). 
the significant issues raised by diversity appeals are institutional and because service in the diversity division may otherwise be regarded as a less attractive assignment. It would not be inappropriate to authorize the administrator to assign occasional cases involving difficult procedural issues to the designated division despite the fact that substantive issues presented indicated different assignments; this would be sensible, for example, in the rare case in which one party is seeking to mount a broad scale attack on a federal rule. ${ }^{214}$ This creates some risk of blurring the divisional lines, but rigid maintenance of these lines is not essential; the parties will receive a full hearing before a fully qualified panel of judges.

Little legislation seems needed to create substantive divisions for courts of appeals. The present provisions of the Judicial Code pertaining to en banc procedure ${ }^{215}$ could be amended to make them inapplicable to circuits of ten or more judgeships. The Code would then provide that such circuits be divided into divisions in accordance with rules of court promulgated by the local Circuit Council, subject perhaps to some minimal statutory standards. With substantive divisions, the courts of appeals could assimilate as many as thirty-five new judgeships, which, on the basis of present output, could handle 2800 appeals a year. Thus, we might hope to preserve for some time the integrity of the law of the circuit without imposing unacceptable burdens on the Supreme Court and without risking any significant changes in the nature of the federal judicial process.

\section{The Circuits and the National LaW}

\section{A. Intercircuit Heterogeneity}

The most telling criticism against the proposal for divisions at the circuit level is that the plan fails to meet the root problem - the instability of intercircuit conflicts produced by the balkanized system of separate circuits. We should face the apparent fact that the national judicial enterprise is outgrowing its central nervous system. Schemes preserving en banc procedure can do no more than avoid aggravation of the ailment; they do nothing to control it. Perhaps the most conservative approach, then, is to seek national uniformity in federal law through restructuring the appellate court system.

Perhaps the most serious drawback of intercircuit heterogeneity is the forum-shopping it encourages, with frustrating con-

${ }^{214}$ See, e.g., Provident Tradesmens Bank \& Trust Co. v. Patterson, 390 U.S. 102 (1968).

21528 U.S.C. $\S 46$ (c) ( 1964$)$. 
sequences for legal planning. To the extent that circuits seem to offer the planner different results, ventures that are only marginal on an economic assessment are overlaid with unresolvable confusion. To be sure, the venue statutes deny a completely open choice of forum, for private litigation generally must be conducted in the district in which the individual defendant resides or in which the cause of action arose. ${ }^{216}$ But in most important litigation, there is at least some range of choice. If the defendant is a corporation, the choice may be as broad as its business activity, for the corporation is deemed to reside wherever it transacts business. ${ }^{217}$ Venue provisions for review of determinations of administrative agencies differ widely, but it is rare that the plaintiff is restricted to one forum. ${ }^{218}$ The Federal Power Commission, for example, can be challenged either in the circuit in which a utility affected by its order has its principal place of business or in the District of Columbia; ${ }^{219}$ the National Labor Relations Board can seek enforcement of its orders in any circuit in which the employer resides or transacts business. ${ }^{20}$ Even more complex are the alternatives open to tax litigants. ${ }^{2 \cdot 1}$ If the taxpayer refuses to pay, the Government will commence collection in the Tax Court, ${ }^{222}$ whose decisions are reviewable in the circuit in which the return was filed. ${ }^{23}$ If the taxpayer pays the tax under protest, he has a choice of forum that includes the collector's district, ${ }^{224}$ his district, ${ }^{225}$ and the Court of Claims. ${ }^{226}$ In fact, the only review of administrative decision which is clearly limited to a single appellate forum is review of licensing proceedings by the Federal Communications Commission. ${ }^{227}$

216 See 28 U.S.C. § I39I(b) (Supp. III, I968).

${ }^{217} \mathrm{Id}$. $\S 139 \mathrm{I}(\mathrm{c})$.

${ }^{218}$ See generally Administrative Conf. of the U.S., Statutory Provisions For Judicial Review of Federal Administrative Action (ig62).

${ }^{210}{ }_{55}$ U.S.C. $\$ 717 \mathrm{r}(\mathrm{b})(1964) ; 16$ U.S.C. $\$ 825 \mathrm{I}(\mathrm{b})(1964)$.

22029 U.S.C. $\$ \mathrm{I} 60$ (e) (rg64).

221 See generally B. Bittker, Federat Income, Estate and Gift Taxatron 934-38 ( 3 d ed. I964).

222 INT. REv. CODE OF 1954 , § 7442.

${ }^{223} I d$. $\S 7482$ (b) ( $\left.\mathrm{I}\right)$. Faced with but one Code and eleven courts of review, the Tax Court does not consider itself bound by the decisions of any circuit-a curiously awkward situation. Compare Arthur L. Lawrence, 27 T.C. 713, 716-20 (1957), with Stacey Mfg. Co. v. Commissioner, 237 F.2d 605 (6th Cir. 1956).

${ }_{224}$ When the District Director is sued individually, venue will usually lie in his district. 28 U.S.C. \& I39r(b) (Supp. III, I968); cf. Farnsworth \& Chambers Co. v. Phinney, 297 F.2d 68I (5th Cir. I962).

${ }^{225}$ When the refund suit is brought against the United States, venue will usually lie in the taxpayer's district. 28 U.S.C. $\$ 1402$ (a) (r964).

${ }^{226} I d$. $\$$ I $49 \mathrm{~g}$. The decisions of the Court of Claims are reviewable only in the Supreme Court, further complicating stability. See 28 U.S.C. $\$ 1255$ (I964),

${ }^{227} 47$ U.S.C. $\$ 402$ (b) (1964) (Court of Appeals for the District of Columbia). 
With such wide choice, forum-shopping to take advantage of intercircuit differences of view cannot be dismissed as trivial. Where the legal consequences of one's actions depend on the complaining party's choice of forum, legal planning - the creation of systems of private ordering - is frustrated. ${ }^{223}$ It would be quite ironic if we should find it necessary to evolve a body of conflict of laws doctrine to be employed by legal planners dealing with intercircuit conflicts. One might suggest half seriously a rule that the law of the circuit in which a contract is made should control its tax consequences, or its enforceability under section zor of the Labor Management Relations Act. Such complexity may be a necessary feature of state-federal or multi-state relations, but it is unbecoming to a single legal system. ${ }^{220}$

A secondary evil of forum-shopping is the "race to the court house" in appeals from administrative decisions, a repugnant development of recent years. ${ }^{230}$ The controlling legislation provides that the choice of forum is determined by the aggrieved party who first files his appeal. ${ }^{231}$ This rule has led to some very marginal claims to be an aggrieved party for the apparent purpose of asserting the choice. ${ }^{232}$ Parties have constructed elaborate systems to assure first filings, and it is no longer extraordinary to find appeals perfected in Chicago, or New Orleans, or Denver, within thirty minutes after the administrative decision has been announced in Washington. ${ }^{233}$ The following description of a race after an NLRB decision in $1964{ }^{234}$ illustrates both the ludicrous

${ }^{228}$ See Hart, supra note 213 , at 505-06.

${ }^{229}$ Concern over this problem has led lawyers and bar groups from time to time to urge consideration of specialized central appellate courts, reserved for such matters as tax litigation. See Lowndes, Federal Taxation and the Supreme Court, I960 Sup. CT. Rev. 222; Griswold, The Need for a Court of Tax Appeals, 57 HARv. L. REv. II 53 (I944). See also p. 604 infra.

${ }^{230}$ See Sunray DX Oil Co. v. FPC, 370 F.2d I8r (Ioth Cir. x966), aff'd in part, rev'd in part, 39r U.S. 9 (I968); Eastern Air Lines, Inc. v. CAB, 354 F.2d 507 (D.C. Cir. 1965); Comment, supra note 187 ; Comment, "Mistake" and Fortum Shopping in Suits for Refund of Federal Tax, II4 U. PA. L. REv. I244 (1966).

${ }^{231} 28$ U.S.C. $\$ 2112$ (a) (Supp. III, 1968).

${ }^{232}$ See, e.g., UAW v. NLRB, 373 F.2d 67x (D.C. Cir. I967); Insurance Workers Union v. NLRB, 360 F.2d 823 (D.C. Cir. I966).

${ }^{233}$ See Comment, Forum-Shopping in the Review of NLRB Orders, $28 \mathrm{U}$. CnI. L. Rev. 552, 562 (196r). This Comment also offers a "forum-shopper's guide"a circuit-by-circuit chart of NLRB appeals. Id. at 553. See also Note, FortumShopping Appellate Review of FTC Cease and Desist Orders, yg68 UTAH L. REv. 316.

${ }^{234}$ General Electric Co., I50 N.L.R.B. I92 (I964). The subsequent history of this litigation is immensely complex. See, e.g., IUE v. NLRB, 343 F.2d 327 (D.C. Cir. I965) (writ to compel NLRB to file record denied, and case transferred to Second Circuit); NLRB v. General Electric Co., 358 F.2d 292 (2d Cir.), cert. denied, 385 U.S. 898 ( 1966 ) (motions to intervene and dismiss various petitions). 
extremes parties are willing to go to and the serious extent to which courts are compromised under such a system of review: ${ }^{235}$

GE, certain that the board would affirm its examiner's findings, was determined to appeal to the courts. And the court in which it wanted to have its appeal heard was the Seventh Circuit Court of Appeals in Chicago. GE didn't say why, but its reason was obvious; the Seventh Circuit court is known as the "company" court. Over the years its decisions have given it the reputation of favoring corporations over labor unions.

At the same time, however, the IUE also was prepared to appeal. Its grounds were to be that the board's findings didn't go as far as the union wanted, but there's the suspicion that the union, knowing GE was determined to appeal anyway, wanted the case heard in a court of its choice - the District of Columbia Court of Appeals. It is no coincidence that the D.C. court is known as the "labor" court.

The day the board's decision was to be announced lawyers for both GE and the IUE arrived at the seventh floor offices of the NLRB in downtown Washington shortly before ro:30 a.m. About 10:30- everyone agreed at the start it was ro:30 though the union lawyer said it looked more like ro:29-Ogden Fields, executive secretary of the NLRB, handed out copies of the decision. Things began to move rapidly.

GE lawyer Thomas F. Hilbert, Jr. scanned the final page of the decision, "saw the board had adopted the order of the trial examiner and that it was necessary for us to ask for a court review," and said "O.K." to a colleague, Robert C. Wentz, a member of GE's employe [sic] relations services. Mr. Wentz, following a union lawyer so closely that "I didn't have to touch the door," nodded to Robert Johnson of GE's communications products department, who was standing at the door to a stairwell across from the NLRB office. Mr. Johnson was carrying in a manila envelope a GE two-way radio. Stepping into the stairwell Mr. Johnson pulled up the antenna and sent a signal to a receiving unit a block away in the law offices of Kenneth C. McGuiness.

Ten minutes earlier, Mr. McGuiness had received a telephone call from Theophil C. Kammholz, a lawyer who was standing in a phone booth on the 27th floor of Chicago's new Federal building. When the signal came in on his radio unit, Mr. McGuiness, who had kept the line open, said "Go ahead." In Chicago Mr. Kammholz shouted "File it" to George Blake of his law firm, who was standing 40 feet away in front of $R$. Hays Blanchard, chief deputy clerk of the Seventh Circuit Court of Appeals. Mr. Blanchard, having quit work two minutes earlier in order to be free for this moment, filed it.

${ }^{235}$ Taylor, Great Court Race-All for Naught, Wall Street Journal, Feb. 24, 1965 , at 18 , col. 3. Reprinted with permission from the Wall Street Journal. Copyright 1965 by the Wall Street Journal Corp. All rights reserved. 
Because the building wasn't finished, there was no clock in the clerk's office. But Mr. Blake, who earlier had synchronized his watch with the Illinois Bell Telephone Co.'s time check and adjusted it so that it was "two seconds slow in comparison to the correct time," thoughtfully provided the time: 9:30:14 a.m. CST — that is, ro: $30: 14$ a.m. EST.

Since the IUE had only a mile to go to reach its court, its preparations weren't quite as extensive as GE's. Nor were they as polished. But they were quick.

When Mr. Fields handed out the decision, a copy was taken by IUE counsel Ben Sigal. Mr. Sigal glanced at the decision and "immediately" nodded to his assistant, Winn Newman, who dashed out the door and down the hall into another office. He then called a pay telephone on the fifth floor of the District of Columbia's Court of Appeals, where Miss Margaret C. Fairbanks was waiting. When the phone rang, she picked it up. Mr. Newman shouted "Go" and Miss Fairbanks leaned out and cried "Winn says go." That cry was heard by Marilyn G. Rose, who then handed the appeal papers to Miss $P$. Casey, a deputy clerk of the court, who glanced at the clock - which had no second hand - and recorded the time.

But there were complications. The time Miss Casey wrote down was I0:25 a.m. - five, or anyhow four, minutes before the decision was handed out. Just before Io a.m. that frantic day there had been a power failure in the courthouse, and its 400 clocks stopped. Though the power came back later, the clocks weren't corrected for two hours. So what time was it?

Miss Rose had synchronized her watch an hour earlier with the Chesapeake \& Potomac Telephone Co., which in turn gets its time from the U.S. Naval Observatory. She said it was 10:30 a.m.

Both sides filed dissents to the time-keeping and eventually the NLRB threw up its hands and said it couldn't determine who filed first. The board proposed instead that the whole mess be filed in the Second Circuit Court of Appeals in New York City, where GE's headquarters are maintained, where the hearings originally had been held and in the district where the unfair acts allegedly had taken place. The District Court of Appeals eventually agreed that it couldn't decide either, and also recommended the Second Circuit. Finally, so did the Seventh Circuit.

Such races may even result in vigorous intercircuit disputes over the jurisdictional issue. ${ }^{236}$ The undesirable consequences of intercircuit forum-shopping might be partially avoided, perhaps, by making the venue requirements more restrictive ${ }^{23 \pi}$ or by revising

${ }^{236}$ See, e.g., Montship Lines, Ltd. v. Federal Maritime Bd., 295 F.2d I47, 150-51 (D.C. Cir. $196 \mathrm{I}$ ). Further, successive orders in the same matter may be reviewed in different courts of appeals. See, e.g., J.P. Stevens \& Co. v. NLRB, 388 F.2d 892 (4th Cir. 1967) ; Midwest Video Corp. v. United States, 362 F.2d 259 (8th Cir. I966). ${ }^{237}$ For further consideration of this possibility see Comment, A Proposal to 
the transfer provision ${ }^{238}$ to make it a more flexible tool with which to force a selection of the best forum, if it can be identified.

Such changes, however, would have little effect on another undesirable consequence of the circuit system: non-uniform treatment of similarly-situated litigants. Proliferation of unequal treatment is an inevitable result of a legal system which operates in disjointed units; that such discrimination is entirely unintended is of little comfort. The recent case of Gondeck v. Pan American World Airways, Inc. ${ }^{239}$ provides a striking illustration of the evil. Petitioner's husband was killed in a jeep accident while working at an Air Force construction site abroad, and the claim arose under the Longshoremen's and Harbor Workers' Compensation Act. ${ }^{2+0}$ She lost in the Fifth Circuit, and the Supreme Court denied certiorari. $^{241}$ Two years later the Fourth Circuit upheld an award in favor of a plaintiff whose decedent had been injured in the same accident. ${ }^{2 \pm 2}$ Shortly thereafter, in an unrelated case, a different panel of the Fifth Circuit expressed doubt about the decision in Gondeck; it suggested that Gondeck was probably inconsistent with the Supreme Court decision it relied on and therefore declined to follow it. ${ }^{243}$ One year later the Court reversed the only decision in direct support of Gondeck. ${ }^{244}$ Although three years had passed since certiorari had first been denied, the widow asked for leave to file a petition for rehearing on the denial, pointing out that she was the only plaintiff with a claim arising from the accident who had been denied relief under the Act. In an unusual action, the Court granted leave to file, vacated the denial of certiorari, granted certiorari, reversed the old judgment of the Fifth Circuit, and rendered judgment for the widow. ${ }^{245}$

So unfairly had the widow been treated by the system of semi-

End the Race to the Cont Honse in Appeals from Federal Administrative Orders, 68 Colum. L. Rev. I66 (Ig68).

${ }^{238}$ Such standards would be excecdingly difficult to supply; $\$ 2$ II2(a) of Title 28 presently provides that the court in which an order is first challenged may transfer the case to another circuit "[f]or the convenience of the parties in the interest of justice ...." 28 U.S.C. $\$$ 2II2(a) (Supp. III, I968). Sober reflection has not suggested a better standard.

${ }^{239} 382$ U.S. 25 (I 965 ).

24033 U.S.C. $\$ \$ 90 I-50$ (I 964$)$.

241 United States v. Pan Am. World Airways, Inc., 299 F.2d 74 (5th Cir.), cert. denied, 370 U.S. $9 \mathrm{r} 8$ ( $\mathrm{r} 962$ ).

242 Pan Am. World Airways, Inc. v. O'Hearne, 335 F.2d 70 (4th Cir. I964).

${ }^{243}$ O'Keeffe v. Pan Am. World Airways, Inc., 338 F.2d 319, 325 (5th Cir. I964), cert. denied, 380 U.S. 95I (1965) (questioning Gondeck's reliance on O'Leary v. Brown-Pacific-Maxon, Inc., 340 U.S. 504 (I95I)).

${ }^{244}$ O'Keeffe v. Smith, Hinchman \& Grylls Associates, Inc., 380 U.S. 359 (1965), rev'g per curiam 327 F.2d 1003 (5th Cir. I964).

${ }^{245} 38$ I U.S. 907 (I965) (granting leave to file); 382 U.S. 25 (I96.5), rev'g per curiam 299 F.2d 74 (5th Cir. I962). 
independent circuits that the Court was impelled to act, but in a manner which raises doubts about the finality of all federal judgments resting on disputable statutory interpretation. ${ }^{246}$ Although the widow's plight was very compelling, her situation was not extraordinary. ${ }^{247}$ There must be many litigants in similar circumstances who accepted their disappointment at the initial denial of certiorari in good grace or in ignorance; there must be many others who failed to file timely petitions because their lawyers recognized that they had little chance. A much larger number of claimants may have failed to appeal, or even to sue, when confronted with a precedent they did not suspect might be overruled..$^{248}$

Regional competition for industry on the basis of favorable application of federal law is another danger. Awareness of this danger has been demonstrated in the past by withdrawal of certain classes of commercial cases from the courts of appeals. The creation of the Commerce Court in I9ro was motivated in part by this concern. ${ }^{240}$ Customs appeals are directed to the central Court of Customs and Patent Appeals partly to avoid any favoritism to particular ports if judicial control were more diffuse. ${ }^{250}$ More recently, it was found necessary to create the wartime Emergency Court of Appeals ${ }^{251}$ to review price and wage regulation because the prospect of regional pricing in a national economy was simply intolerable. ${ }^{252}$ The structure of the courts of appeals was not intended to allow regional adaptation of federal law. On the contrary, the legislative history of the Evarts Act ${ }^{253}$ indicates that these courts were intended to harmonize and unify the national law, not to fragment it. Further, circuit regionalism violates the premise of the commerce clause and other provisions of article II of the Constitution that national uniformity is desired

\footnotetext{
${ }^{246}$ See O'Leary v. Brown-Pacific-Maxon, Inc., 340 U.S. 504 (I95I).

${ }^{247}$ An carlier, more modest reopening of a denial of certiorari in order to correct a conflict was United States v. Ohio Power Co., 353 U.S. 9S (1957). See also Cahill v. New York, N.H. \& H.R.R., 35I U.S. 183 (I956) (per curiam) (relied on by Justice Clark in his concurring opinion in Gondeck, 382 U.S. at 28).

${ }^{248}$ See also Bros Inc. v. W.E. Grace Mfg. Co., 320 F.2d 594 (5th Cir. 1963) (similar problem involving FED. R. CIv. P. 60(b)).

${ }^{249}$ Act of June I8, I9ro, ch. 309,36 Stat. 539.

${ }_{250}$ Act of Aug. 5, 1909, ch. 6, $\$ 29,36$ Stat. ro5 (codified as amended in scattered sections of 28 U.S.C.). See also F. FRANKFuRTER \& J. LANDis, stipra note 7 , at 15 I.

251 Emergency Price Control Act of 1942, ch. 26, § 204, 56 Stat. 31.

${ }^{252}$ See Yakus v. United States, 321 U.S. 414, 432-33 (1944). See generally Sprecher, Price Control in the Courts, 44 Colum. L. Rev. 34 (1944).

${ }^{253}$ See generally StafF of the Senate Comm. on the Judiciary, supra note I65.
} 
on many subjects of federal legislation. ${ }^{254}$ It would be a most peculiar scheme of government whose judiciary made decisions in the regional interest without the support or restraint of any politically responsible executive or legislative officials. The needs of regionalism are adequately protected by a healthy respect for federal-state relations and, in exceptional circumstances, by federal legislation which explicitly incorporates state law. ${ }^{255}$

Finally, it may be emphasized that a consequence of the system is to increase administrative discretion. An administrator who loses in court tends to regard the reversal as an isolated event and in his dealings with the public may even discount the intermediate court decision. Because the executive branch has through the Solicitor General unavoidably great influence on the Supreme Court in the exercise of its certiorari power, it can in substantial measure prevent doubts it may welcome from being resolved. So pressed is the Court by the certiorari burden that it must rely in substantial measure on his guidance in selecting cases worthy of its review. Inevitably, and without the least guile on the part of anyone, this dependence builds into the system a factor favoring the positions taken by the agencies.

The problems created by the practical limitations on the Supreme Court's powers of review are not limited to the courts of appeals. In addition to the fewer than ninety cases from the lower federal courts on which the Supreme Court renders full opinions each year, ${ }^{2-56}$ it renders full opinions on only half that many cases coming from other courts subject to its review. ${ }^{257}$ An annual state-case average of less than one case per state per year is obviously an inadequate basis for assuring equal administration of federal rights in all the state courts. Neither the removal jurisdiction ${ }^{258}$ nor the availability of post-conviction relief ${ }^{259}$ are adequate remedies for this problem. The risk of contumacy is surely greater with respect to state courts than with respect to federal, ${ }^{260}$ and the likelihood that state judges will be unable to comprehend and assimilate the national law is at least as great as the likelihood that federal judges will err in its application. ${ }^{201}$ While the need for expanding Supreme Court ability to review may, then,

${ }^{254}$ Cf. Martin v. Hunter's Lessee, I4 U.S. (I Wheat.) 304, 347-48 (I8I6) (Story, J.); Wisdom, sttpra note $20 \mathrm{r}$, at 426-27.

${ }^{255}$ See, e.g., 18 U.S.C. $\$ \mathrm{r}_{3}$ (I964). See generally H.M. HART \& H. WeChSLER, supra note 50 , at $456-57$.

${ }^{250}$ The Supreme Court, 1967 Term, 82 HaRv. L. Rev. 63, 304-05 (Ig68).

${ }^{257}$ During the 1967 Term, the Supreme Court decided 39 state court cases with full opinions. Id. at 305. See generally Hart, sutpra note 48 .

${ }_{258}^{28} 28$ U.S.C. $\$ \S I 44 I-50$ (I 964$)$.

250 Id. $\$ 2254$ Supp. II, 1967).

${ }^{280}$ See, e.g., Baker v. State, 245 Ind. I29, I95 N.E.2d 9I (Ig64).

${ }^{281}$ ALI STuDY, supra note $4 \mathrm{I}$, at $67-74$. 
be more pressing with respect to state than federal cases, that is no reason to postpone attempts to resolve the federal dilemma.

\section{B. Toward a National Law}

Commentators have suggested two approaches to the problem of heterogeneity in the national law: specialized courts and increased stratification of the appellate hierarchy. Each approach would itself appear to create serious problems.

I. Specialized Appellate Courts. - In the past Congress' response to the need for national uniformity of federal law in a particular subject matter has often been the creation of a specialized court. The simplest model is suggested by the Court of Customs and Patent Appeals, ${ }^{202}$ whose specialized judges hear all customs appeals. ${ }^{203}$ Some years ago Erwin Griswold suggested a similar approach for a Court of Tax Appeals, to be composed of specialists exercising exclusive jurisdiction over all tax appeals, whether decided initially in the Tax Court, a district court, or the Court of Claims. ${ }^{204}$ This proposal would eliminate the present structural instability in the national revenue law resulting from the rule that the appeal from the Tax Court is taken in the taxpayer's home circuit, and appeal from a district court is taken in "the circuit embracing the district." 26i"

The objections to specialization, noted above, ${ }^{260}$ apply in force to a specialized court along these lines. But they have little application to a specialized court staffed with generalized judges. A model for a national court of this type is the Emergency Court of Appeals, which was created to stabilize the national law of price control. ${ }^{207}$ Its jurisdiction, originally limited to matters arising under the Emergency Price Control Act of 1942, was ultimately enlarged to include the Housing and Rent Act of I $948^{268}$ and the Defense Production Act of $1950^{.60}$ In nineteen years 676 cases were filed and terminated in that court, with

${ }^{202} 28$ U.S.C. $\$ \$ 211-16$ (Ig64). See generally Graham, The Court of Cusloms and Patent Appeals, Its History, Functions and Jurisdiction, I FED. B. Ass'N J., Oct. r932, at 33 .

${ }^{263}$ Its jurisdiction over patents is, however, in part shared with the district courts. See 28 U.S.C. $\$ 1338$ (a) (1964). See also note 285 infra.

${ }^{264}$ Griswold, supra note 229. See also Traynor, Administrative and Judicial Procedure for Federal Income, Estate, and Gift Taxes-A Criticism and a Proposal, 38 CoLum. L. Rev. 1393 (1938); p. 597 supra.

${ }^{265}$ INT. Rev. CODE OF I954, § $7482 ; 28$ U.S.C. § 1294 (I964).

${ }^{266}$ See pp. 590-92 supra.

207 The court was created by section 204(c) of the Emergency Price Control Act of 1942 , ch. 26, 56 Stat. 32 .

268 Act of Mar. 30, I948, ch. I61, \& 202 (d), 62 Stat. 97.

${ }^{269}$ Act of Sept. 8, I950, ch. 932, $\$ 408,64$ Stat. 808. 
no more than eighty heard in a single year. ${ }^{270}$ Five judges, appointed from the corps of federal judges by the Chief Justice, were assigned to the court, but since they sat in panels of three, it was not a full-time position; most of their energies were devoted to their permanent assignments. By giving priority to the work of the special court, they were able to decide the Emergency Court cases quickly.

Unfortunately, this model cannot be made to perform too broad a role. A part-time court would not in ordinary course be reasonably accessible, as to time and place of hearing, to litigants spread across the country. Also, either the court's docket or its jurisdiction would have to be restricted; if too many cases were assigned, too many part-time judges would be needed, and gains in stability would be lost.

Access and stability are not the only limiting considerations; permanent assignment, although one means of handling a large docket, also would invite specialization. The small docket of the Emergency Court of Appeals kept it a part-time court, allowing its judges to have a reasonably generalized exposure in their permanent assignments. A comparable result, also through assignment, might be achieved by a limited term. ${ }^{2 i 1}$ An optimal solution consistent with stability might be to staff specialized courts with part-time judges who are serving limited terms and limit the docket to 250 filings a year. This would produce halftime employment for seven judges. As the number of filings increased beyond that figure, it would become necessary either to add judges, and thus greatly compound the problem of coordination among panels, or to take a larger portion of the seven judges' time, and thus risk excessive specialization. The problem becomes circular: the latter problem might be alleviated by a more rapid turnover, but that would aggravate the problem of doctrinal stability over time.

This inelasticity in optimum docket size suggests a need for docket control. A specialized court might have control over its docket much as does the Supreme Court, taking only selected cases within its jurisdiction and leaving the rest to the general courts. Under this plan, the court could also solve the collateral problem of delay through congestion. But there would be a cost in the time and energy expended in the screening enterprise, as well as some risk of instability in the cases not transferred to its docket. The latter risk could be mitigated by giving the special-

\footnotetext{
270 See Transcript of Proceedings of the Final Session of the Court, United States Emergency Court of Appeals, 299 F.2d I, I7 (I96I) (annual figures based only on years $1944-55)$.

${ }^{271}$ See p. 590 supra.
} 
[Vol. 82:542

ized court a revisory power, perhaps in the form of a transfer and rehearing en banc after initial disposition by the general court. En banc proceedings would be required; otherwise, unnecessary friction might be generated by the refusal of the special court to accord the same respect to a local panel as it might give to one of its own panels. The en banc format for review of panel decisions would also limit the frequency of such review, thereby avoiding the intrusion of a complete fourth tier. If these two features, docket control and revisory power, were incorporated into the plan, the optimal docket size would have to be reduced, perhaps to 200 filings a year, but the court's potential responsibility would extend over matters producing a much larger number of filings.

The problem of geographical inconvenience might be attacked by providing transportation for counsel to the central place of hearing at public expense. This reimbursement could also include reasonable compensation for travel time. Since centralization serves a public purpose, it is arguably unfair to burden litigants with these costs. Furthermore, the United States, very frequently a party before the specialized courts, would have its overall litigation budget favored by increased stability, and it does not seem unreasonable to apply these savings to compensate private litigants. Indeed, the argument seems compelling as cases are selected from a larger group on the basis of the public interest. There can be little justification for making a particular litigant bear the added costs of sending his lawyer to Chicago or Washington under these circumstances. ${ }^{272}$

Jurisdictional problems raised by specialized courts could be easily met. The jurisdictional lines of a welter of specialized courts, if neatly drawn, should raise few questions of where to perfect an appeal. Also, a court to which a case seems misassigned should have the power to correct the mistake; an appeal timely perfected in any appellate court could on proper motion be transferred without penalty. Overlapping, analogous to difficulties in assignment of cases in the divisional scheme, ${ }^{273}$ would be unimportant, for rarely would any case raise more than one issue of sufficient importance to merit review within the jurisdictions of the specialized courts.

Selecting the personnel for such courts raises special problems. The usual method of appointing federal judges seems unsuitable because the hazards of political influence would be

\footnotetext{
${ }^{272}$ This would, of course, require a considerable enlargement of the recent legislation authorizing judgments for costs against the United States; that legislation seems plainly a step in the right direction. See Act of July 18, 1966, Pub. L. No. 89-507, 8I Stat. 308, amending 28 U.S.C. $\$ 2412$ (1964).

${ }^{273}$ See p. 594 supra.
} 
aggravated with respect to specialized appointments, and the specialized courts would constitute yet another level of federal judicial rank and thus complicate the problem of recruitment. Appointment might be limited to judges from the existing corps of circuit and district judges, as was done with the Emergency Court. In addition to confining political influence, this limitation would assure some protection to the status of the district and circuit judges. Also, the power to reassign those selected to their original positions would give the special court plan some flexibility during its early years.

Although the selection could be by the President, as is now the practice for the special courts, alternatives more distant from the political arena should be considered. The judges for the Emergency Court were selected by the Chief Justice, but this plan has the disadvantage of placing him in a position where strong pressure may be applied. Putting the decision in the hands of the members of the Supreme Court would absorb the Court's valuable time and impair the personal independence of the lower federal judges. Another alternative would be to put the burden of selection on the circuit judges, operating through the Circuit Councils with each circuit being entitled to some rough approximation of per capita representation. This would have some possible disadvantages, however, in localizing the constituencies of the national judgeships, and spoiling relations among the members of the circuits. To some extent, these dangers might be minimized by giving the circuit Justice a role to play in the selection, perhaps requiring his presence at the Council meeting. Perhaps the best approach would be to vest the power of appointment in the Judicial Conference of the United States. ${ }^{274}$ Because he could surely influence the selection through the committee structure of the Conference, this plan assures some of the advantages of leaving the decision with the Chief Justice. It would also give representation to the lower federal judiciary through the chief judges and elected district judge representatives, while avoiding the pitfalls of selection in Council.

Thus, the Emergency Court of Appeals suggests a number of variations which bear consideration. A single design would not necessarily be the best for all purposes. Furthermore, it would seem wise to tailor any program of development of specialized courts to existing institutions, some of which now serve the need for stability with varying measures of success. The problems may be further illuminated by a consideration of some possible uses of specialized courts.

${ }^{274}$ The composition of this organization is prescribed by 28 U.S.C. $\S 33 \mathrm{r}$ (I964). 
Perhaps the area in greatest need of national uniformity is review of decision of administrative agencies regulating business. An agency often faces review in eleven appellate courts. Regional variations are thoroughly exploited in this area, for these matters tend to involve large sums of money; it is primarily here that the techniques of forum-shopping have developed to such a high level. Finally, the unfortunate economic consequences of regional discrimination are very real. It is presumably for these reasons that review of the Interstate Commerce Commission was given special treatment under the Urgent Deficiencies Act, which accorded a right of review in the Supreme Court. ${ }^{275}$ The Court of Appeals for the District of Columbia presently serves as a sort of national court for administrative review, and is staffed by judges appointed from the entire country. Venue of review of the regulatory commissions could be restricted to that court. One division might be a national transportation court, and a second review other agencies, such as the Federal Power Commission, the Federal Communications Commission, and possibly the Securities and Exchange Commission. It was once more true than it is today that the District of Columbia court was the center of administrative litigation. ${ }^{276} \mathrm{~A}$ policy of decentralization was adopted evidently to improve access for litigants and to decentralize the bar practicing the specialities involved. Neither of these reasons seems substantial today. At the trial level, these agencies are generally accessible to litigants, for their trial examiners are transient, and all that is involved at the appellate hearing is the access of the litigant's lawyer. Travel time no longer compels reliance on Washington counsel, and the cost of transportation is usually only a flyspeck on the cost of this kind of litigation, easily assimilated as a cost of operating the businesses involved. ${ }^{277}$

A second area, and the one in which the arguments for national stability are most vigorous, ${ }^{278}$ is the review of tax decisions. The duty of the Government to be even-handed in the

${ }^{275}$ Act of Feb. II, I903, ch. 544, § 2, 32 Stat. 823.

${ }^{276}$ For the most recent decentralization see Act of Oct. 5, 1962, Pub. L. No. 87-748, 76 Stat. 744 (codified at 28 U.S.C. \$\$ 136I, 139I(e) (1964)). See Byse, Proposed Reforms in Federal "Nonstatutory" Judicial Review: Sovereign Immunity, Indispensable Parties, Mandamus, 75 HaRv. L. REv. 1479 (1962).

${ }^{277}$ Some special exceptions might be appropriate. The cost may not be insignificant for some affected litigants, such as those faced by SEC cease and desist orders. In such cases, the added costs might be borne by the Government. An alternative would be to deny such cases access to this court.

${ }^{278}$ I am indebted to my colleague, Alan N. Polasky, who has served on the project of the American Bar Foundation devoted to the study of tax procedurc. Many of the ideas advanced here originate with him, although he bears no responsibility for the conclusions tendered. 
collection of revenue is beyond debate. The small handful of these cases which the Supreme Court is able to take each year is wholly inadequate to stabilize the administration of the law. At present, about $45^{\circ}$ tax cases are filed in the courts of appeals every year, and the range of differences in the standards of review imposed by the various courts creates an elasticity that significantly enlarges the range of discretion of the Commission$\mathrm{er}$, even at the lower levels at which tax returns are audited. The Service has made a substantial effort to harmonize its own practices with internal controls, but these are to some extent subverted by the disjointed system of review. The only virtue of the present system, easier access to the reviewing court, perhaps could be accommodated if the Government bore the additional litigants' costs in centralized review, at least in cases involving smaller amounts of revenue. The argument for this proposal would be more compelling if the specialized court exercised docket control, as would be necessary if it were to have a caseload manageable by a compact group of judges. Special consideration must be given the Court of Claims, which exercises a concurrent jurisdiction with the courts of appeals in tax matters. ${ }^{270}$ It seems fair to say that the role of the Court of Claims in the administration of the tax law is an anachronism, which serves today only to provide an opportunity for forum-shopping. ${ }^{280}$ One solution would be to include the Court of Claims in the structure of the Court of Tax Appeals by rotation of its judges through that court, and giving that court dominion over tax cases filed in the Court of Claims, to the extent that its own docket is discretionary. Simpler, perhaps, would be the abolition of its tax jurisdiction.

This last might be viewed as a part of a program to rationalize the role of the Court of Claims. That court has now emerged as an article III appellate court, ${ }^{281}$ and this development suggests a possible enlargement of its role with respect to claims. Tort claims against the United States, many smaller contract claims, and many property disputes involving the United States are tried in district courts in order to ensure reasonable access to litigants and the bar. There is considerably less reason for

278 This jurisdiction is based on the Tucker Act, 28 U.S.C. § I49I (rg64).

${ }^{280}$ For a sanguine view of the consequences of this opportunity see Miller, Tax Litigation in the Court of Claims, 55 GEo. L.J. 454 (I966). But cf. Ferguson, Jurisdictional Problems in Federal Tax Controversies, 48 Iowa L. REv. 312 (Ig63).

${ }^{281}$ Primary decision making in claims cases is generally done by commissioners. The pattern of procedure contemplated for the court by Congress in the Act of May II, I966, Pub. L. No. $89-425,80$ Stat. I39, closely resembles that of a court of appeals of seven judges. See Jacoby, Recent Legislation Affecting the Court of Clains, 55 Geo. L.J. 397, 398-99 (I966). 
decentralizing the process of review, ${ }^{282}$ and it might well be appropriate to direct appeals in these classes of cases to the Court of Claims, or the Court of Claims Appeals, as it might become. Possibly included, also, might be appeals involving the exercise of the eminent domain power and appeals involving subcontract disputes under the Miller Act.

Suggestions have recently been advanced for changes in the structure of the Court of Customs and Patent Appeals. One view is that the court should be subordinated to the Court of Appeals for the District of Columbia, where, perhaps, its decisions might receive closer attention than they are able to command in the Supreme Court. ${ }^{283}$ Another view is that the court should be reformed to ensure its members more general experience by giving it an excess of judgeships so that its members could be used more extensively on courts of appeals ${ }^{284}$ and by enlarging its jurisdiction to include copyright matters. Both of these proposals have some merit in ensuring an end to some of the instability of concurrent patent jurisdiction. ${ }^{285}$ Another approach seems even more attractive, for patents and copyrights are part of a larger problem that could perhaps be given unified treatment. Trademark and unfair competition problems arising under the Lanham Act ${ }^{286}$ are obviously very closely allied, and the monopoly elements in all these are related to government antitrust cases. ${ }^{28 \pi}$ It might be wise to bring them all within a

\footnotetext{
${ }^{282}$ The new legislation authorizes the court to sit anywhere in the United States. See 28 U.S.C. \& I 75 (Supp. III, I968).

${ }^{283}$ President's Comm. on the Patent System, "To Promote the Progress of ... Useful Arts" in an Age of Exploding TeChnology 27 (1966).

284 ABA Section of Patent, Trademark, and Copyright Law, supra note 194.

${ }^{285}$ A problem of overlapping jurisdiction remains. Patent appeals may be divided into two types, one stemming from the patent and trademark application procedure (whether a patent will or will not be issued), and another from so-called interference proceedings. 28 U.S.C. \& 1542 (1964). In each case, an appeal to the Court of Customs and Patent Appeals is one of two available appellate remedies. See 35 U.S.C. \$§ I4I, 145, I46 (I964); I5 U.S.C. § I07I (I964). The other involves an appeal in the District Court for the District of Columbia in the case of an appeal from the Board of Appeals (application process) and any proper district court in an appeal from the Board of Interference Examiners. Choice of one forum waives any access to the other. Appeals are limited to final orders only and are based on the record below. New evidence, however, is admissible, and the parties are entitled to a trial de novo on the evidence, though new issues cannot be raised. See Wilson Jones Co. v. Gilbert \& Bennett Mfg. Co., 332 F.2d 216 (2d Cir. 1964$)$.

${ }^{286} 15$ U.S.C. $\S \S$ I051-1 127 (Supp. III, 1968).

${ }^{287}$ Appeals in government antitrust cases now go directly to the Supreme Court. I5 U.S.C. $\& 29(1964)$. This practice has been under severe criticism for some time. See Currie, The Three Judge District Court in Constitutional Litigation, 32 U. CHI. L. Rev. I, 75 n.367 (1964); Gesell, A Much Needed Reform-
} 
specialized jurisdiction, along with other private disputes involving issues of federal commercial law, such as private treble damage suits and review of Federal Trade Commission orders. This may seem to be a broad reach for one specialized court, but, except for the patent litigation, the number of cases in each of the classes mentioned has been small in recent years. ${ }^{288}$

Finally, the field of labor relations, including review of NLRB orders, is worthy of notice. The problem of national heterogeneity is at its worst here, and forum-shopping abounds. But on closer examination, labor relations does not seem suited for a special court. The Supreme Court adequately oversees this area, taking a large number of labor cases for review. Furthermore, the real problem of stability in this field lies deeper than doctrinal pronouncement, for differences in personal attitudes toward the disputants are quite sharply defined. Not only would the problems of selecting the members of the national court be especially acute, but also the countervailing need for access is more important in labor cases, for not infrequently they involve marginal economic values.

The cumulative effect of relying on the development of the existing national courts, including the Court of Appeals for the District of Columbia, the Court of Claims, and the Court of Customs and Patent Appeals, would pose a serious threat to the status of the regional courts of appeals, for with all government claims, administrative review, and trade matters withdrawn from the general jurisdiction, the remaining docket would be less attractive to possible recruits for the judgeships. In shaping particularized responses, this problem should be borne in mind. Perhaps, for example, if the Court of Customs and Patent Appeals were to be enlarged and upgraded, its judgeships might be gradually put into rotation, as temporary assignments for circuit judges. Possibly, the judgeships of the Court of Claims and the Court of Appeals for the District of Columbia might be placed in rotation as temporary assignments. Although this need not be done with respect to every specialized court suggested, it would surely be a mistake to create many new national responsibilities for judges sitting permanently in Washington, thereby elevating their status at the expense of those sitting elsewhere.

It is not the purpose of this article to advocate firm accep-

Repeal the Expediting Act for Antitrust Cases, I96r N.Y.S.B.A. ANTrtrust Law Symposium 98; Note, Direct Appeals in Antitrust Cases, 81 Harv. L. Rev. 1558 (1968). But see Celler, Case in Support of Application of the Expediting Act to Antitrust Suits, I4 DePaul L. ReV. 29 (x964).

${ }_{288}^{28}$ The filings for all reviewing courts in 1967 included 127 patent cases, 23 trademark cases, 83 antitrust cases, and r9 FTC cases. See Ig67 ANNUAL REPORT 186, I92-93. 
tance or final rejection of proposals for additional specialized appellate courts; much less is it the purpose to advocate any particular form for such tribunals. But it does attempt to demonstrate that there is a case in the national interest for special appellate courts. These proposals must be freed from stigmatization as the product of the grasping efforts of specialized segments of the bar to advance the interests of their particular craft by creating institutions that will be responsive only to specialized advocacy and that will create doctrine that will be comprehensible only to those with the trained incapacities of experts.

2. Towards a New National Court. - An alternative approach to the problem of national uniformity is to extend the vertical structure of the federal courts by creating a general, national circuit above the courts of appeals which would handle most of the intercircuit conflicts which the Supreme Court no longer has the time to resolve. At the outset, the cost in prolonging litigation inherent in such an approach must be acknowledged. Three decades ago, Roscoe Pound took occasion to applaud the demise of the nineteenth century practice of multiple appeals, ${ }^{289}$ while extolling the virtues of directness and simplicity in the appellate process. Even if the present system is more expensive and cumbersome than Pound admitted, we should be loath to multiply the burdens. Further, we are asked to trade the intangible ills of an unstable legal system for the tangible ills of a more expensive one. But before rejecting the idea out of hand, we should examine suggestions for restructuring the courts of appeals that call for other than the creation of a complete fourth tier.

A plan suggested by Frederick Wiener would create three or four regional courts, each of which would have the power of review over two or three circuits. ${ }^{200}$ This proposal, however, fails to accomplish the basic objective of a national court, for it leaves multiple law-making units which would still divide the national law by regions. Indeed, reducing the number of circuits in conjunction with the plan proposed above for the operation of the large circuit ${ }^{201}$ could lower the number of circuits to seven, providing almost as much relief as the Wiener plan without its attending costs. If the First Circuit were merged into the Second, the resulting court would still not be as heavily burdened as the Fifth is today, and would be more manageable because

\footnotetext{
${ }^{289}$ R. Pound, Appeilate Procedure in Civil Cases 327 (I94I).

${ }^{290}$ Wiener, Federal Regional Courts: A Solution for the Certiorari Dilemma, 49 A.B.A.J. 1169 ( 1963 ).

${ }^{291}$ See pp. 587-90 supra.
} 
of its smaller size. Likewise, some of the medium-sized circuits could perhaps be merged: the Third with the Fourth; the Sixth with the Seventh; the Eighth with the Tenth. Because of its peculiar political composition, the District of Columbia does not seem to be eligible for such a marriage; the Fifth and the Ninth Circuits are large enough, certainly, without one.

The costs of a fourth tier can be avoided, and its benefits obtained, by a different means. The judicial power presently exercised by the courts of appeals en banc ${ }^{202}$ could be vested in a single court, organized into divisions along substantive lines similar to those suggested above for the large circuits. This proposal would allow systematic institutional discipline without making multiple review generally available. To the new court would be assigned fifteen judges sitting in three divisions, each having control over its docket, selecting for review only cases raising troublesome issues. While it would have power to revise panel decisions by means of a rehearing similar to that now possible before a court of appeals en banc, some of its cases might be taken by transfer before panel decisions are made, thus expediting the termination of litigation. To avoid specialization the judges might be selected from among the existing corps of federal judges for a limited term of nine years, and no judge would devote more than a few years to any single division before rotating to another. After serving a term on such a court, judges would return to their former duties, or would attain senior status.

Each division could be expected to decide as many as 150 to 200 cases a year. The 450 to 600 cases decided by the whole court each year would increase the number of federal appellate decisions of general, national impact by a multiple as large as seven, sufficient to have a major impact on the problem of the instability of the national law. Such a court would obviate the need for en banc procedures in the circuits, and thus without sacrificing the character of the process of review eliminate ceilings on the number of circuit judgeships which could be created to meet the caseload.

Such a court would also have advantages over a series of specialized courts. Its harmonizing influence would be felt in areas which the special courts would not reach, while there would be no need to disturb existing judicial institutions. Also, the Court of Claims and the Court of Customs and Patent Appeals would be subordinate to this court, thus providing the needed coordination between those courts and the regional courts of appeals.

Without docket control similar to that exercised by the Supreme Court, the "National Circuit" would quickly become a

${ }^{202}$ See pp. 580-82 supra. 
fourth tier, with a caseload that would preclude unified action. But if the Supreme Court were accessible only through the National Circuit, the new court could, through the control of its own docket, control that of the Supreme Court, and so create an unacceptable competition in the eyes of litigants between the two courts. An alternative would be to permit the Supreme Court to control both dockets through the certiorari process, assigning to the National Circuit those cases which were regarded as important, but not important enough to command the rationed attentions of the Supreme Court. This, however, would make the National Circuit an auxiliary to the Supreme Court and place its independence in question. The best system seems to be a dual selection process, with petitions for certiorari being filed simultaneously with the Supreme Court and the National Circuit; these could also serve as petitions for rehearing in the latter court. Although this has the appearance of duplicating the screening work, the two courts would surely learn to look for somewhat different features in selecting cases for review. The Supreme Court would no longer interest itself in circuit conflicts, leaving many areas of the national law almost entirely to the attention of the National Circuit. In contrast, the National Circuit would have a much lower threshold of interest than the Supreme Court. If both courts selected the same case, it would be heard only in the Supreme Court. The Supreme Court would retain power to entertain petitions for review of decisions in the National Circuit, but it is to be expected that it would exercise this power only in the very extraordinary situation in which the National Circuit seems to have departed drastically from principles clearly established by the Supreme Court.

With this system in force, there seems to be no risk that the seniority of the Supreme Court would be effectively challenged by the members of the National Circuit bench. As members of a larger group than the Supreme Court, serving not for life but for a limited term, the judges of the National Circuit would pose no competitive threat to the dignity of the Supreme Court Justices. They would, however, be in a position to perform a role which the Supreme Court has had increasing difficulty in filling. Similarly, the creation of the National Circuit would not be the occasion for any denigration of the office of circuit or district judge, because of the contemplated selection process. Selection would be made on a merit basis, preferably by the Judicial Conference or a similar institution, and only sitting federal judges with significant experience would be eligible. With this prospect in view, the circuit judgeship is made a more, not a less, attractive office. Harm to the morale of those judges who are not se- 
lected for service on the National Circuit is difficult to assess, but we may expect that mature professionals would not be permanently embittered by such disappointments, especially if they are permitted to participate at least in a vicarious way in the process of selection. Further, the creation of this court would enable us to maintain the federal appellate system in a way that is consistent with high levels of craftsmanship while eliminating congestion. The continued opportunity to participate in careful decision making on a wide range of problems should more than offset any injury to the morale of the "ordinary" circuit judge who continues to serve in the regional circuits,

The cost to the national treasury in creating fifteen new judgeships would be low, at most two million dollars a year, ${ }^{293}$ and might be offset by potential economies from the additional stability which might discourage some litigation. The cost to private litigants also should not be unacceptable. First, it should be emphasized again that the National Circuit would not be a fourth tier in the sense that litigants would be expected to work their way through it as a road to the Supreme Court, for the National Circuit would be reviewing cases different from those reviewed by the Supreme Court. Second, many of the cases heard in the National Circuit might be transferred prior to regional panel hearings on the motion of either party or of a circuit judge assigned to hear the case, or sua sponte by the National Circuit. A model for this practice can be found in the Supreme Court of New Jersey, which grants certiorari, on motion or sua sponte, in most of its cases before the intermediate court has heard them. ${ }^{294}$ Indeed, the present federal statute permits the Supreme Court to take cases from courts of appeals before decision. ${ }^{205}$ The National Circuit might well make better use of this power. There would, however, be some increase in upper level review in the federal courts; it is expected that, as a percentage of the number of cases decided by panels, the rate of upper level review would be restored to the level of a few decades ago. The added expense in the few cases - those which would not have

203 This seems a generous estimate, though no thorough cost-accounting has been done. The payroll cost of a judge and his staff is presently less than $\$ 75,000$ a year. For another estimate see Letter of Judge Albert V. Bryan to Will Shafroth, in Shafroth, supra note 33 , at $3 \mathrm{I} 4$.

204 N.J. C. R. I:Io-I and -IA. A survey of the Annual Reports of the Administrative Director of the New Jersey Courts indicates that about $3 / 4$ of the supreme court's cases are taken before hearing in the intermediate court; a majority of these are transferred by the court sua sponte, the rest on motion.

${ }^{205} 28$ U.S.C. \$ I254(I) (I964). E.g., Youngstown Sheet \& Tube Co. v. Sawyer, 343 U.S. 579 (1952); United States v. United Mine Workers of America, 330 U.S. $25^{8}$ (I947). 
been heard en banc or accepted by the Supreme Court, or which were not taken by the National Circuit before appellate decision - should not be ignored. The burdens borne by these few litigants will achieve a net economy for their class because others similarly situated may be saved the cost of the first appeal, and perhaps even the much greater cost of a trial. For this reason, it would be appropriate for the public to bear the added expense of litigants who have no personal long-range interest beyond the outcome of their own cases but whose cases have been selected for continued litigation in the national interest. ${ }^{206}$ Such litigants might include the seaman or government tort claimant, who after winning in the court of appeals, must litigate in the National Circuit. The added cost could be limited to travel and its incidents if review in the National Circuit were treated as a rehearing on the same briefs submitted to the regional panel. Also, the National Circuit might be closed to those classes of cases, such as Jones Act claims, in which there is a serious risk of injustice from added expense. There is precedent for this type of exception in the removal statute, ${ }^{207}$ which forbids removal of some kinds of cases which otherwise would be subject to the original jurisdiction of the district courts, because of the special danger that the inaccessibility of the federal court might be used as a club by removing defendants.

The proposal for a National Circuit is tendered with great diffidence, for it rests on assumptions that many can reasonably dispute. But an objection going to the validity of the whole argument may be expected from those who are deeply committed to the methodology of modern social science. With so much of what has been said here nondemonstrable, many surely will be reluctant to make a decision about changes in the structure of the federal courts without much more precise statistical analysis of the problem and its causes, and of the alternative solutions and their effects. Admirers of the scientific method, who are possessed of a distaste for the navel-gazing so often tendered as research, will be tempted to urge that the problem should be shelved until we know more than we do now about the practical consequences of the alternatives. But there are sound reasons for resisting this temptation.

First it must be borne in mind that the legal process is more than a device for social control; it is also a ritual of symbolic importance, expressing the attitude of the community toward itself and its members. A primary objective is to satisfy those

${ }^{296}$ It must be noted that these same arguments can be made for the costs of Supreme Court review's being borne by the public in analogous situations.

20728 U.S.C. \& I 445 ( 1964 ). 
who observe and participate in the ritual, by giving expression to their aspirations for the community. The critical problem may therefore be one of deciding what it is that we wish to express through the process. For such a task, introspection may be a more appropriate tool than statistical sampling.

Moreover, even if we were to focus only on the pragmatic consequences of one proposal or another, there is enormous frustration in seeking to apply scientific techniques to behavior as complex as litigation. The information gathered by the Administrative Office of the United States Courts has been carefully studied: support can be found in that data for a wide variety of conflicting assumptions. Furthermore, there are no known or presently conceivable methoas which can measure the amount of doctrinal stability now enjoyed, much less a method for evaluating the change likely to result from any of the alternative proposals.

As with other problems of gradually wasting assets, there is no urgency about preserving the effectiveness of the courts of appeals, for there is not any point in time at which drastic consequences will suddenly result if the trend toward greater congestion is not stopped. Few litigants have sufficiently numerous contacts with the courts to see the disintegrative process at work or to feel directly prejudiced by it. A lowering of our expectations for the national judicial process and an unreflective adaptation to its defects require less effort than a determined effort to cope with the causes of the decline. But lack of public interest in the problem merely increases the responsibility of the profession to find a solution.

Decisions must be made now. There can be no dispute about the fact that a return to the theory and practice of the Evarts Act and the Act of 1925 is now impossible, for events have laid waste the simple concept of the intermediate courts these Acts contemplated. All of the possibilities, including inaction, incur costs and risks. Indeed, the choice of inaction is, in this instance, the most speculative course, for we cannot predict with any confidence where it will lead. Perhaps the slack will be taken up by heavier reliance upon the legislative or executive branches of the government. Of these, the latter seems more likely. Possibly, we will witness some decline in the role of the national law as a vital part of our national life. Paradoxically, purposeful reform that will adapt our judicial institutions so they can continue their present role is the most conservative choice. 